\title{
Uncertainty and Overfitting in Fluvial Landform Classification Using Laser Scanned Data and Machine Learning: A Comparison of Pixel and Object-Based Approaches
}

\author{
Zsuzsanna Csatáriné Szabó ${ }^{1, *(1)}$, Tomáš Mikita ${ }^{2}$ (), Gábor Négyesi ${ }^{3}$, Orsolya Gyöngyi Varga ${ }^{4}$, \\ Péter Burai ${ }^{5}$, László Takács-Szilágyi ${ }^{4}$ and Szilárd Szabó ${ }^{3}$ (D) \\ 1 Department of Physical Geography and Geoinformatics, University of Debrecen, Doctoral School of Earth \\ Sciences, Egyetem tér 1, 4032 Debrecen, Hungary \\ 2 Department of Forest Management and Applied Geoinformatics, Mendel University, Zemědělská 3, \\ 61300 Brno, Czech Republic; tomas.mikita@mendelu.cz \\ 3 Department of Physical Geography and Geoinformatics, University of Debrecen, Egyetem tér 1, \\ 4032 Debrecen, Hungary; negyesi.gabor@science.unideb.hu (G.N.); szabo.szilard@science.unideb.hu (S.S.) \\ 4 Envirosense Hungary Ltd., 4281 Létavértes, Hungary; orsolya.varga@envirosense.hu (O.G.V.); \\ laszlo.takacs@environse.hu (L.T.-S.) \\ 5 Remote Sensing Centre, University of Debrecen, Böszörményi út 138, 4023 Debrecen, Hungary; \\ burai.peter@unideb.hu \\ * Correspondence: szabo.zsuzsanna@science.unideb.hu; Tel.: +36-52-512-900/22201
}

Received: 20 October 2020; Accepted: 5 November 2020; Published: 7 November 2020

\begin{abstract}
Floodplains are valuable scenes of water management and nature conservation. A better understanding of their geomorphological characteristic helps to understand the main processes involved. We performed a classification of floodplain forms in a naturally developed area in Hungary using a Digital Terrain Model (DTM) of aerial laser scanning. We derived 60 geomorphometric variables from the DTM and prepared a geomorphological map of 265 forms (crevasse channels, point bars, swales, levees). Random Forest classification was conducted with Recursive Feature Elimination (RFE) on the objects (mean pixel values by forms) and on the pixels of the variables. We also evaluated the classification probabilities (CP), the spatial uncertainties (SU), and the overfitting in the function of the number of the variables. We found that the object-based method had a better performance (95\%) than the pixel-based method (78\%). RFE helped to identify the most important 13-20 variables, maintaining the high model performance and reducing the overfitting. However, CP and SU were not efficient measures of classification accuracy as they were not in accordance with the class level accuracy metric. Our results help to understand classification results and the specific limits of laser scanned DTMs. This methodology can be useful in geomorphologic mapping.
\end{abstract}

Keywords: geomorphometry; terrain analysis; floodplain; random forest; F1; recursive feature elimination

\section{Introduction}

Rivers, through erosion and accumulation processes generate various landforms in their floodplains [1-3]. Among them, levees, located next to the active or abandoned channels, are the most elevated forms; they can even be a couple of meters higher than the surrounding areas. Due to their position, they may provide the most critical controls on floodplains, determining the distribution of water and sediment $[4,5]$. The surface of levee's can be dissected by crevasse channels, which operate only during floods and have a crucial role in delivering water and sediment between the channel 
and its surrounding landforms [6,7]. Usually, within a meander loop, juxtaposed point bars and swales are formed as a consequence of the lateral migration of a meandering river [8,9]. The ridges are approximately on the same level as the middle height channel, while the swales are in between with a concave shape $[10,11]$. Oxbow lakes, paleo river channels and backswamps belong to the lowest elevation areas of floodplains; therefore, they serve as sediment traps and are often marshy areas [12-14]. All these varied landforms make the surface of the floodplains a complex geomorphic landscape [15-17].

Floodplains are important scenes of habitat protection as the conditions for intensive agriculture are often poor. Although there are some ploughed lands, large areas remain undisturbed due to the regular or seasonal water coverage. These areas can be a refuge for several endangered and/or valuable species. The landforms of the floodplain can predetermine the species distribution with their water retention and water supply through the terrain height and the groundwater level [18-20]. Furthermore, they also define the ecological succession paths of the vegetation and create a mosaic structure of the landscape [21,22]. The habitats of the floodplain only connect to the river during a flood, but this has a huge ecological importance due to the different activities (shelter, reproduction, feeding) of living organisms. When this hydrological connection does not exist, lentic water becomes isolated, and can therefore provide specific habitat [23]. Furthermore, the vegetation gradually covers the variant geomorphological landforms: the slowly replenishing lakes (e.g., oxbow lakes, backswamps) are usually first covered by pondweed, then by water caltrop and finally by reed; the flooded grasslands of the floodplains (e.g., point bars, swales) are enfolded by typha, sedge and other grasses. The unflooded parts of the floodplain (e.g., levees) are naturally covered by soft-wood and hard-wood forests because they avoid longlasting water coverage [21]. Consequently, floodplains function as stepping stones and green corridors in the landscape, and are biodiversity hotspots [24]. Thus, the identification of the fluvial forms of a floodplain can provide important information for nature protection, and for landscape planners employed by water authorities.

Conventional topographic maps only delineate larger landforms, usually, for example, oxbow lakes, paleo channels and deeper swales with water coverage, but do not include many of the landforms that are also important determining factors of the habitats present on the floodplains. The development of technology for data collection provides new dimensions in examining the land surface more precisely. In recent years, LiDAR DTMs (Light Detection And Ranging based Digital Terrain Models) have become indispensable tools in fluvial geomorphology [25]. We can find many examples of their application: they have been used for hydraulic modelling [26,27], assessment of fluvial processes [28], mapping of sedimentary environments [29], modelling the extent of inundation [30,31], and levee profiling [32,33]. With the spread of computer-based terrain analysis tools, we can derive a large and increasing number of quantitative descriptors or measures (called terrain attributes or morphometric variables) of the land [34-36]. Computerized terrain analysis allows us to explore the geomorphometric characteristics of land surfaces and forms, to identify and classify discrete hydrologic and geomorphic units, and to have a better understanding of landscape processes [37-40]. Primary terrain attributes, such as slope, aspect and curvature, are computed directly from DTMs, as they are significant in determining runoff rate, geomorphology and soil water content [41,42]. Secondary attributes, such as the topographic wetness index and the topographic position index, are derived from two or more primary attributes, offering an opportunity to depict pattern as a function of process [41]. Both types of terrain attributes are valuable tools of feature extraction in geomorphometry. 
Previously, several studies [43-46] have dealt with feature extraction in floodplains, but these were usually not aimed directly at describing the fluvial forms. In our previous work [47], we aimed to extract swales and point bars with primary terrain attributes and the Normalized Difference Vegetation Index (NDVI), and we found that the overall accuracy (OA) of the classification of the forms was $71 \%$. However, geomorphometric indices, including secondary attributes, may help to gain better results; furthermore, misclassifications can also be reduced with the inclusion of more fluvial forms, such as crevasse channels and levees. A large number of variables raises the issue of overfitting; thus, an important step should be the variable selection, the identification of the most important geomorphometric indices that make the largest contribution to gaining the best classification accuracy, which can also be applicable in other areas, too.

In this study, our aim was to reveal the efficiency of terrain attributes in fluvial landform (point bar, swale, levee, crevasse channel) classification. We hypothesized that (i) geomorphometric variables can identify fluvial forms, (ii) a larger number of predictor variables improve the classification accuracy and decrease the uncertainty, (iii) overfitting is the function of the number of variables, (iv) the number of predictor variables can be reduced and, with a proper feature selection, 5-10 terrain attributes can also reduce overfitting, and (v) an object-based method outperforms the pixel-based approach.

\section{Materials and Methods}

\subsection{Study Site}

Our study area is located in northeast Hungary, in the floodplain of the Tisza River below the confluence of the Bodrog River (Figure 1). The Tisza River becomes a typical plain-tract river here [48]. The study site extends over approximately $10 \mathrm{~km}^{2}$ and is very rich in fluvial landforms. Extensive farming activity is present here, which helps maintain the land close to its natural condition. The most typical landforms of the floodplain are scroll patterned landforms formed of point bars and swales left by the lateral migration of the Tisza River. They roll off the floodplain and make its surface wavy. Some of them are still very conspicuous, while others are rusty or filled in, making the differences between the forms faint. Some deeper and wider swales contain wet and marshy parts and dense aquatic vegetation, while others do not. The point bars are mostly without water and dense vegetation, expect in rare cases in which they are situated in a relatively low part of the floodplain. Solitary trees and groups of trees are present in both forms. An extensive levee lies next to the Tisza River, its surface dissected by natural crevasse channels at many points. This levee is used as arable land. A less conspicuous levee is situated next to a paleo river channel. Two backswamps and an oxbow lake can be also found on the study site. There are artificial crevasse channels between some forms to help the movement of water. Some forms had been already delineated and labelled (e.g., oxbow lake: Sulymos-Lake, paleo channel: Kis-Morotva-Lake, swale: Nagy-Zátony-Lake) in the Hungarian national 1:10,000 scale topographic maps. 


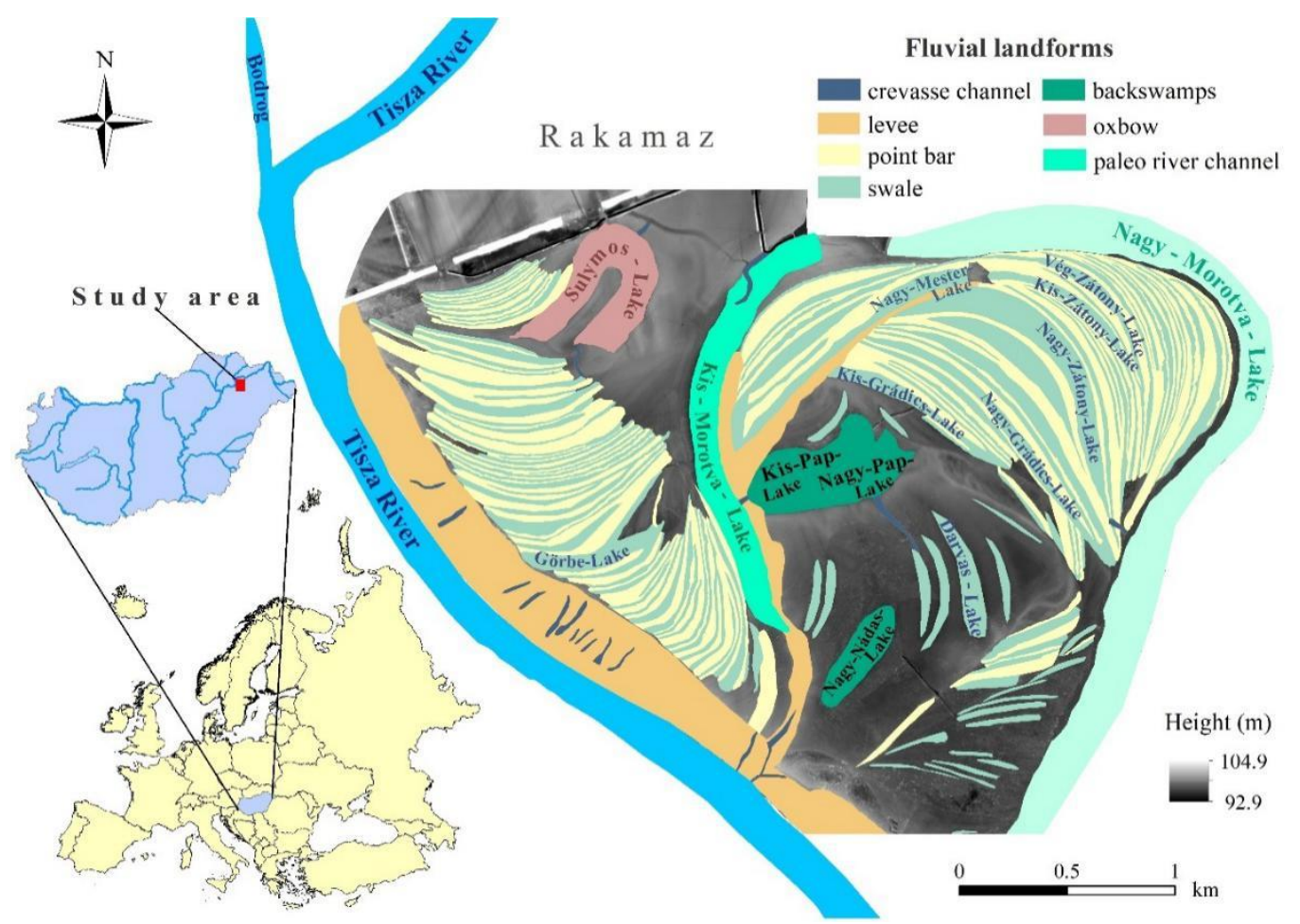

Figure 1. The location of the study site and the fluvial forms.

\subsection{Data Set and DTM Generation}

The aerial survey of the study area was carried out by a Riegl LMS-Q680i aerial laser scanner in the framework of the SH/2/6 program in August 2012 [49] by Envirosense Ltd. The predetermined point density was 4 point $/ \mathrm{m}^{2}$, and the accuracy was $\pm 15 \mathrm{~cm}$ both vertically and horizontally. Our base dataset was the point cloud provided by the Trans Tisza Water Directorate. We conducted noise reduction with the neighbourhood distance based method and ground point classification with Cloth Simulation Filters (CSF) [50]. The DTM was generated from the ground points with the Natural Neighbour interpolation method at a resolution of $1 \mathrm{~m}$ with $0.18 \mathrm{~m}$ RMSE (Root-mean-square error) in the ESRI ArcGIS 10.3.1 software environment [51].

\subsection{Terrain Analysis}

We conducted a geospatial analysis with two open access software programmes, SAGA GIS (System for Automated Geoscientific Analyses Geographic Information System) 6.3.0 [52] and Whitebox GAT (Geospatial Analysis Tools) 3.4.0 [53] and we determined 60 terrain attributes from the DTM including basic parameters such as aspect, slope, gradient, curvatures, and secondary attributes such as the wetness index, the multiresolution index of valley bottom/ridge top flatness, mass balance and the convergence index (Table 1). Furthermore, there was an opportunity to use algorithms to determine the flood order for each of the cells within the DTM and to carry out elevation residuals analysis [53]. Some terrain attributes had tuning parameters; thus, in these cases, we repeated the calculations with different settings (e.g., difference from the mean elevation tool with 8, 16, 32 search neighbourhood sizes) to find the most suitable one for the characterisation. 
Table 1. The terrain attributes derived from the DTM.

\begin{tabular}{|c|c|c|c|c|c|}
\hline ID $^{1}$ & Terrain Attributes * & Description & Abbreviations & Settings & References \\
\hline 1 & Flood Order & $\begin{array}{l}\text { It creates the flood order of grid cells, which are encountered during a search, starting from the raster } \\
\text { edges and the lowest cell, moving inward at increasing elevations. }\end{array}$ & FlodO & - & {$[53,54]$} \\
\hline 2 & Elevation Relative To Min and Max & $\begin{array}{l}\text { It expresses the elevation of a grid cell in the DTM as a percentage of the relief between the DTM } \\
\text { minimum and maximum values. }\end{array}$ & ElRel & - & [53] \\
\hline 3-5 & Deviation from Mean Elevation & $\begin{array}{l}\text { The difference between the elevation of each cells and the mean elevation of the centering local } \\
\text { neighborhood, normalized by standard deviation. }\end{array}$ & $\begin{array}{l}\text { DevME1 } \\
\text { DevME2 }\end{array}$ & $\begin{array}{l}\text { Search Neighborhood } \\
\text { Size: } 8 \\
\text { Search Neighborhood } \\
\text { Size: } 16\end{array}$ & {$[41,53]$} \\
\hline $6-8$ & Difference from Mean Elevation & $\begin{array}{l}\text { The difference between the elevation of each grid cell and the mean elevation in its local neighborhood (a } \\
\text { user-specified rectangular area). }\end{array}$ & $\begin{array}{l}\text { DevME3 } \\
\text { DifME1 } \\
\text { DifME2 } \\
\text { DifME3 }\end{array}$ & $\begin{array}{c}\text { Search Neighborhood } \\
\text { Size: } 32 \\
\text { Search Neighborhood } \\
\text { Size: } 8 \\
\text { Search Neighborhood } \\
\text { Size: } 16 \\
\text { Search Neighborhood } \\
\text { Size: } 32\end{array}$ & {$[41,55]$} \\
\hline $9-10$ & $\begin{array}{l}\text { Maximum Elevation Deviation (Multiscale) } \\
\text { Scale } \\
\text { Magnitude }\end{array}$ & $\begin{array}{l}\text { It calculates the maximum value of deviation from mean elevation across a range of spatial scales. One of } \\
\text { the two output rasters is a raster containing the scale at which the maximum occurred (scale). The other } \\
\text { output is a raster containing this maximum deviation value (magnitude). }\end{array}$ & $\begin{array}{c}\text { MxEMs } \\
\text { MxEMm }\end{array}$ & $\begin{array}{l}\text { Defaults } \\
\text { Maximum Neighborhood } \\
\text { Radius (cell): } 1498\end{array}$ & [55] \\
\hline 11 & Depth in sink & A depression depth for each depression cell. & DpthS & - & {$[53,56]$} \\
\hline 12 & Downslope Index (radius) & $\begin{array}{l}\text { A measure of the slope gradient, within a specified radius, between a cell and the nearest downslope } \\
\text { location that represents a specified vertical drop. }\end{array}$ & DwnsIR & Head potential drop (d): 2 & {$[53,57]$} \\
\hline 13-15 & Elevation Percentile & It calculates the elevation percentile based on an image histogram in a user-specified window. & $\begin{array}{l}\text { ElevP1 } \\
\text { ElevP2 } \\
\text { ElevP3 }\end{array}$ & $\begin{array}{l}\text { Search Neighborhood } \\
\text { Size: } 8 \\
\text { Search Neighborhood } \\
\text { Size: } 16 \\
\text { Search Neighborhood } \\
\text { Size: } 32\end{array}$ & [53] \\
\hline 16 & Map Gully Depth & $\begin{array}{l}\text { It calculates using the difference from the mean elevation and accounts for the fact that gullies are } \\
\text { differentiated from ravines or larger valleys because they have widths and maximum cross-sectional } \\
\text { depths that are less than the specified parameters (the maximum gully width, the minimum and } \\
\text { maximum gully depths, a threshold in difference from the mean elevation, a plan curvature threshold, and } \\
\text { a smoothing parameter). }\end{array}$ & MapGI & - & [53] \\
\hline 17 & Multiscale Elevation Residual Index & $\begin{array}{l}\text { It uses a range of spatial scales to describe the relative landscape position of a location. For each grid cell, } \\
\text { it calculates the difference from the mean elevation. }\end{array}$ & MltERI & - & [55] \\
\hline 18 & Maximum Downslope Elevation Change & The maximum elevation drop between each grid cell and its neighbor cells in a $3 \times 3$ window. & MxDwEC & - & [53] \\
\hline 19 & Minimum Downslope Elevation Change & The minimum elevation drop between each grid cell and its neighbor cells in a $3 \times 3$ window. & MnDwEC & - & [53] \\
\hline 20 & Sediment Transport Index & $\begin{array}{l}\text { The transport capacity index. It combines the upslope contributing area, in accordance with the } \\
\text { assumption that the contributing area is directly related to discharge and slope. }\end{array}$ & SedTI & - & {$[58,59]$} \\
\hline 21 & Wetness Index & The TOPMODEL index. It describes the spatial distribution of zones of saturates. & WetnsI & Defaults & {$[59,60]$} \\
\hline 22 & Aspect & The direction in which the steepest slope of the plane tangent faces (slope azimuth). & Asp & Defaults & [61] \\
\hline 23 & Slope & The angle made by the plane and the horizontal surface (slope gradient). & Slope & Defaults & [61] \\
\hline 24-27 & $\begin{array}{l}\text { SAGA Wetness Index } \\
\text { Catchment Area } \\
\text { Catchment Slope } \\
\text { Modified Catchment Area } \\
\text { Topographic Wetness Index }\end{array}$ & $\begin{array}{l}\text { The wetness index describes the tendency of a location to accumulate water. The catchment area is the } \\
\text { area that drains into the catchment outlet. The catchment slope is the average slope over the catchment. } \\
\text { The modified catchment area is based on a calculation, which does not assume that the flow is a very } \\
\text { thin film. }\end{array}$ & $\begin{array}{c}\text { CatchA } \\
\text { CatchS } \\
\text { ModCA } \\
\text { TWI }\end{array}$ & $\begin{array}{l}\text { Defaults } \\
\text { Defaults } \\
\text { Defaults } \\
\text { Defaults }\end{array}$ & {$[36,41]$} \\
\hline
\end{tabular}


Table 1. Cont.

\begin{tabular}{|c|c|c|c|c|c|}
\hline $\mathrm{ID}^{1}$ & Terrain Attributes * & Description & Abbreviations & Settings & References \\
\hline 28 & Convergence Index & $\begin{array}{l}\text { It calculates an index of convergence (negative value)/divergence (positive value) regarding the overland } \\
\text { flow, using the aspect or gradient of the surrounding cells. It is similar to the plan curvature, but does not } \\
\text { depend on absolute height differences. This version uses a filter of } 2 \times 2 \text { or } 3 \times 3 \text { cells. }\end{array}$ & Convi & Defaults & {$[62,63]$} \\
\hline 29 & Convergence Index (Search Radius) & This version of the convergence index uses a search radius. & ConvISR & Defaults & {$[62,63]$} \\
\hline 30-31 & $\begin{array}{l}\text { Downslope Distance Gradient } \\
\text { Gradient } \\
\text { Gradient Difference }\end{array}$ & $\begin{array}{l}\text { It measures downslope controls on local drainage. There are two output layers: one is the gradient, the } \\
\text { other is the difference from the local gradient. }\end{array}$ & $\begin{array}{c}\text { Grad } \\
\text { GradDif }\end{array}$ & $\begin{array}{l}\text { Defaults } \\
\text { Defaults }\end{array}$ & {$[57,64]$} \\
\hline 32 & Plan Curvature & The curvature in the horizontal plane (contour or horizontal curvature). & PlanCurv & Defaults & [61] \\
\hline 33 & Profile Curvature & $\begin{array}{l}\text { The slope variation in the vertical plane (slope profile curvature). The importance of this is that it reveals } \\
\text { the character of the surface (convex, concave, horizontal). }\end{array}$ & ProfCurv & Defaults & {$[61,65]$} \\
\hline 34 & Tangential Curvature & The plan curvature multiplied by the sine of the slope. & TangCurv & Defaults & {$[41,65]$} \\
\hline 35 & Cross-Sectional Curvature & $\begin{array}{l}\text { The tangential curvature intersecting with the plane defined by the normal surface and a tangent to the } \\
\text { contour. }\end{array}$ & CrSCurv & Defaults & {$[52,66]$} \\
\hline 36 & Longitudinal Curvature & $\begin{array}{l}\text { The profile curvature intersecting with the plane defined by the normal surface and maximum gradient } \\
\text { direction. }\end{array}$ & LongCurv & Defaults & {$[52,66]$} \\
\hline 37 & General Curvature & The second derivative value of a surface; a general measure of the land convexity. & GenCurv & Defaults & {$[59,65]$} \\
\hline 38 & Maximum Cuvature & The maximum convexity in any plane. & MaxCurv & Defaults & {$[66,67]$} \\
\hline 39 & Minimum Curvature & The minimum convexity in any plane. & MinCurv & Defaults & {$[66,67]$} \\
\hline 40 & Total Curvature & Used as a measure of surface curvature. & TotCurv & Defaults & [41] \\
\hline $41-45$ & $\begin{array}{l}\text { Upslope and downslope curvature } \\
\text { Local Curvature } \\
\text { Upslope Curvature } \\
\text { Downslope Curvature } \\
\text { Local Upslope Curvature } \\
\text { Local Downslope Curvature }\end{array}$ & It calculates the local curvature of a cell as the sum of the gradients to its neighbor cells. & $\begin{array}{l}\text { LocCurv } \\
\text { UpSICurv } \\
\text { DwSlCur } \\
\text { LUpSCurv } \\
\text { LDWSCurv }\end{array}$ & $\begin{array}{l}\text { Defaults } \\
\text { Defaults } \\
\text { Defaults } \\
\text { Defaults } \\
\text { Defaults }\end{array}$ & {$[52,68]$} \\
\hline $46-49$ & $\begin{array}{l}\text { Multiresolution Index of Valley Bottom Flatness } \\
\text { Multiresolution Index of Valley Bottom } \\
\text { Flatness } \\
\text { Multiresolution Ridge Top Flatness Index }\end{array}$ & $\begin{array}{l}\text { Multiresolution index of valley bottom flatness identifies valley bottoms using their flatness and lowness } \\
\text { characteristics. Lowness is measured by a ranking of the elevation in a circular area, and flatness by the } \\
\text { inverse of the slope. The multiresolution ridge top flatness index identifies ridge tops. It uses a very similar } \\
\text { method to MRVBF, only the upper parts of the landscape are identified from the elevation percentile. }\end{array}$ & $\begin{array}{l}\text { MRVBF1 } \\
\text { MRVBF2 } \\
\text { MRRTF1 } \\
\text { MRRTF2 }\end{array}$ & $\begin{array}{l}\text { Defaults } \\
\text { Initial threshold for slope: } \\
8 \\
\text { Defaults } \\
\text { Initial threshold for slope: } \\
8\end{array}$ & [69] \\
\hline 50 & Topographic Position Index & $\begin{array}{l}\text { It compares a cell value to the mean value of its neighbors in a user-specified window. Positive values are } \\
\text { features, which are typically higher than surrounding ones, negative values represent lower features, and } \\
\text { values near to zero are either flat or areas of constant slope. }\end{array}$ & TPI & Defaults & [70] \\
\hline $51-52$ & Multi-Scale Topographic Position Index & $\begin{array}{l}\text { The topographic Position Index (TPI) compares the elevation of each cell to the mean elevation of what } \\
\text { surrounds that cell. Multi-Scale-TPI calculates the TPI for different scales and integrates these into one } \\
\text { single layer. Positive values are higher (ridges); negative values are lower (valley) than their surroundings. }\end{array}$ & $\begin{array}{l}\text { MS-TPI1 } \\
\text { MS-TPI2 }\end{array}$ & $\begin{array}{l}\text { Defaults } \\
\text { Min Scale: } 8 \\
\text { Max Scale: } 8\end{array}$ & {$[41,70,71]$} \\
\hline $\begin{array}{l}53 \\
54\end{array}$ & $\begin{array}{l}\text { Generalized Surface } \\
\text { Morphometric Protection Index }\end{array}$ & The smoothed input DTM. & GenSurf & Defaults & {$[52,66]$} \\
\hline 55-56 & $\begin{array}{l}\text { Morphometric Protection Index } \\
\text { Valley Depth } \\
\text { Valley Depth } \\
\text { Ridge Level }\end{array}$ & $\begin{array}{l}\text { It analyses the surroundings of each cell up to a given distance and indicates how the reliet protects it. } \\
\text { Ridge level is calculated by the vertical distance to a channel network base level. Valley depth is calculated } \\
\text { as the difference between the elevation and the ridge level. }\end{array}$ & $\begin{array}{l}\text { Protlnd } \\
\text { Valdpth } \\
\text { RidgLvl }\end{array}$ & $\begin{array}{l}\text { Defaults } \\
\text { Defaults } \\
\text { Defaults }\end{array}$ & {$[40,73]$} \\
\hline 57 & Diurnal Anisotropic Heating & It uses slope and aspect and addresses diurnal heat balance as influenced by topography. & DiurnAH & Defaults & {$[34,74]$} \\
\hline 58 & Morphometric features & $\begin{array}{l}\text { A multi-scale approach. It classifies morphometric features (peaks, ridges, passes, channels, pits and } \\
\text { planes) on the DTM using the slope, aspect and curvature of the surface. }\end{array}$ & MorfFeat & Defaults & [66] \\
\hline 59 & Terrain Ruggedness Index & It measures the terrain ruggedness by using the sum of changes in elevation within an area. & TRI & Defaults & [75] \\
\hline 60 & Vector Ruggedness Measure & $\begin{array}{l}\text { It combines the aspect and slope to quantify terrain ruggedness by measuring the dispersion of vectors } \\
\text { orthogonal to the terrain surface. }\end{array}$ & VRM & Defaults & [75] \\
\hline
\end{tabular}

* (IDs of 1-21 were computed in WhiteGATBox software environment and 22-60 were computed in SAGA GIS.). The Italics mean the category name of that morphometric variables, which are in below mentioned. 


\subsection{Preprocessing of Input Data for Model Building}

The first step was to develop a geomorphology map of the fluvial forms of the area; such a map was generated in our previous work [47] by visual interpretation of available aerial photos and the DTM combined with field mapping. The map was edited in the GIS environment and was the input database of all analyses with 265 geomorphological features (105 point bars, 127 swales, 20 crevasse channels, 13 levees; the 2 levees of the study site were divided into subsections to ensure more features were included in the analysis).

\subsection{Model Building}

\subsubsection{Variable Selection}

As 61 (the DTM and its 60 derived attributes) variables cause serious issues regarding overfitting, we intended to reduce the number of predictors; accordingly, we applied the Recursive Feature Elimination (RFE) technique. RFE was used directly with the classification algorithm (in our case with the Random Forest) based on the following theory: variables with the least contribution to overall accuracy are omitted from the set of predictors through iterations. Thus, the initial model considers all predictors and after removing one variable the model is rebuilt and run again. This process lasts until only one variable (with the largest contribution) remains in the model. Finally, the result is the rank of predictors based on their importance in making a contribution to obtaining greater classification accuracy [76]. We applied the RFE with a 10-fold cross-validation with 3 repetitions in R 4.03 with the caret package [77].

\subsubsection{Supervised Classification Procedure}

Random Forest (RF) is a robust and popular classifier in the remote sensing community because it does not make assumptions on normal distribution and variance homogeneity but its classification performance is high $[78,79]$. RF, as a classifier, has proved its efficiency in satellite imagery based land use studies [80-82], in urban studies based on aerial photography [83] and even in geomorphological object identification using DTMs [84,85]. Accordingly, we also chose RF as a supervised classification method.

Having the rank of predictor variables derived from RFE, i.e., knowing the predictor-set of the optimal predictor variable number that ensures the highest overall accuracy, we conducted model runs involving a decreasing number of variables with the RF classification. We removed one variable at a time with the lowest contribution until only one variable remained. We applied 500 trees, as earlier studies reported that errors stabilize before 500 trees are achieved [86]. Furthermore, the mtry parameter (the optimal number of variables for splitting at nodes) had been optimized to obtain the greatest accuracy: models were run with increasing mtry values from 2 to 30, and the best model was chosen based on the highest Overall Accuracy. All models were run with a 10-fold cross validation with 3 repetitions. This may seem redundant with the RFE; however, the result was an optimized model that can also be used for prediction, which was applied in the uncertainty analysis.

We aimed to identify swales, point bars, levees, and crevasse channels as the most frequent forms of the study area. Classification was performed with both (1) pixel-based (PB) and (2) object-oriented (OO) approaches (Figure 2). 


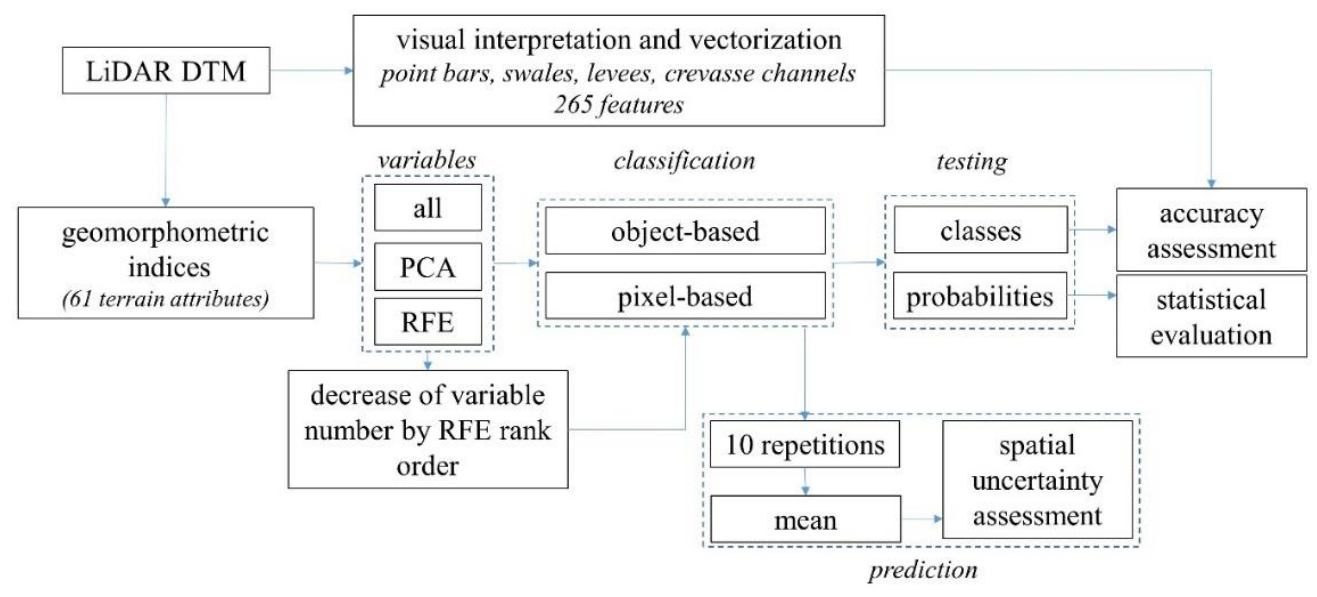

Figure 2. The workflow of the analysis.

1. We used the vector layer as reference data of the fluvial forms: stratified random sampling was carried out and we chose 5000 pixels for training and 5000 pixels for testing.

2. Polygons of the reference vector layer were used as objects; thus, the object-oriented term did not mean automatic segmentation, but real fluvial objects interpreted in a visual way. We determined the mean values of the DTM and the 60 derived raster layers by geomorphological features.

Both pixel sampling and mean value extraction were performed in ESRI ArcGIS 10.3.1 [51]. Classifications were performed in R 3.6.3 (R Core Team, 2020) with the rpart [87] and caret packages [77], and in EnMAP-Box (Environmental Mapping and Analysis Program) 2.1.1 software [88].

\subsection{Model Evaluation and Uncertainty Analysis}

We used the geomorphological map (see Section 2.4) as the reference dataset: in the OO-approach, the dataset was randomly split into training and testing, in a 50-50 ratio; in the PB-approach, we generated a stratified random sampling with 10,000 points within the polygons of the forms, split randomly into 5000 training and 5000 testing datasets.

We determined the Overall Accuracy (OA) as a general index of classification performance (Equation (1), [89]), and the F1 [90] for each class (Equation (2)).

$$
\begin{gathered}
\mathrm{OA}=(\mathrm{TP}+\mathrm{TN}) /(\mathrm{TP}+\mathrm{TN}+\mathrm{FP}+\mathrm{FN}) \\
\mathrm{F} 1=(2 \mathrm{TP}) /(2 \mathrm{TP}+\mathrm{FP}+\mathrm{FN})
\end{gathered}
$$

where TP: true positive, TN: true negative, FP: false positive, FN: false negative number of classifications.

While the OA provides a general evaluation of classifications and makes it possible to compare different model performances, the F1 is the harmonic mean of the Producers' and Users' Accuracy (UA and PA) [91], and evaluates the class level performance.

For the evaluation of model performances, we applied a 10-fold cross-validation with 3 repetitions (RKCV): the training dataset was divided into 10 subsets of which 9 were used to train a model and one to test it; in the next step, another 9 subsets were used to train another model and the remaining subset for testing. The process finished when all subsets had been used for testing; finally, the whole procedure was repeated with another two randomly selected subsets, resulting in 30 models. We reported the medians of the OAs of the 30 models, and each OA was calculated on the test data (i.e., independently of the training dataset).

Next, we calculated the OAs and F1s using the test dataset, and also the "out-of-the-box" accuracies using the training dataset for testing, which was important to determine the level of overfitting (see Section 2.8). 
Beside the thematic accuracy, we also evaluated the probabilities: RF classifications rely on the highest probability assigned to the classes (in our case fluvial forms); thus, to explore the variation in the maximal probability, the values per form provide important information [92].

The RF algorithm uses random selection of input data for the numerous (in our case 500) decision trees in different model runs, thus, theoretically, models cannot be repeated, i.e., all models are different. However, R (and Python) software provides the possibility of a repetition with the same result (random sets should be defined). We performed the predictions with the optimized model with 10 different random sets. While repeated cross-validation produced 30 models, providing a thorough analysis using the mean, median, standard deviation, and interquartile range of each model, it only used the reference dataset.

A spatial analysis was performed with the predictions: we used the whole data of the study area and we calculated the uncertainty. We repeated the predictions with 10 different RF models with the models of different numbers of input variables $(20,15,10,9,8,7,6,5,4,3,2)$. Then, we determined the mean values of the 10 predictions, and we expected the following coded landforms: 1 (as crevasse channels), 2 (as point bars), 3 (as swales) and 4 (as levees). If all predictions of the repetitions resulted in the same code, numbers would be whole and identical with the expected classes' number, but if the prediction resulted in different morphological forms (i.e., classes), the mean would be a number with fractions. Thus, if we count the number of whole numbers where the results are fractions, we can visualize and express the level of uncertainty in the predictions.

Furthermore, beside the classifications, we also calculated the probabilities associated with the given pixels. R software provides the probabilities for each class and we combined the chosen class and the related probability to the reference pixels. Thus, we were able to evaluate the interaction of the class level probabilities and the effect of the number of variables.

\subsection{Predictor Stability Analysis}

Predictors, i.e., geomorphometric variables, were selected by the RFE variable selection method, but the selection is a function of the input data. Accordingly, we also studied the selected variables of the RFE. We had set 11 different random samples with 1000 pixels from the 5000 training pixels and, using the RFE with 10-fold cross-validation with 3 repetitions, we determined the rank orders of the 11 realizations and we then evaluated and summarized the rank orders by their frequency.

\subsection{Analysis of Overfitting}

As a measure of overfitting, we determined the OA, both with the training dataset (i.e., dependent on the model, OAtrain) and the testing dataset (independent of the model, OAtest). The difference between the two types of accuracies revealed whether the classification performance was the function of a large number of variables (Equation (3)).

$$
\text { Overfitting }=\mathrm{OA}_{\text {train }}-\mathrm{OA}_{\text {test }}
$$

where OA is the Overall Accuracy.

\subsection{Statistical Evaluation}

We determined the Pearson correlation coefficients among the geomorphometric variables and visualized the results in a correlation plot grouped by hierarchical clustering with the Ward method. Nominal variables had been omitted. The correlation structure's internal consistency was quantified with Cronbach's $\alpha$. If all variables correlate, $\alpha=1$, and when variables do not have any correlation with the other, $\alpha=0$ [93]. We also determined $\alpha$-values per variable, which helped to find the metrics that deteriorate the internal consistency. 
We applied General Linear Modelling (GLM) to reveal the relationship among the class level accuracy measure, the F1, the type of fluvial forms (as factor) and the number of variables (as covariate) [94]. Assumptions were checked with the Shapiro-Wilk test (normality) and the Levene test (variance homogeneity). Partial contributions of the independent variables were reported with the effect size $\left(\omega^{2}\right)$ [95]. Statistical analysis was performed in R 4.03 with the gamlj and corrplot packages $[96,97]$.

\section{Results}

\subsection{Results of Data Preprocessing}

First, we conducted PCA (Principal Component Analysis) on the variables of the pixels extracted from the raster layers (PB-approach), which indicated a good fit (Root Mean Square Residual RMSR $=0.05$ ); however, the first five PCs explained only $73 \%$ of the total variance and several variables had poor $(<0.5)$ community values. After excluding 11 variables $(\mathrm{MnDwEC}$, Aspect, CatchA, DiurnAH, ValDpth, ModCA, MRRTF1, MRRTF2, PlanCurv, TotCurv, ConvI), the model fit was the same $($ RMSR $=0.05)$, but the explained total variance changed to $78 \%$ (Table 2$)$.

Table 2. Principal components (PC1-5) of the PCA conducted on all variables of pixels extracted from fluvial forms.

\begin{tabular}{cccccc}
\hline Statistic & PC1 & PC2 & PC3 & PC4 & PC5 \\
\hline SS loadings & 10.31 & 8.69 & 8.58 & 4.18 & 2.55 \\
Proportion variance & 0.23 & 0.20 & 0.20 & 0.09 & 0.06 \\
Cumulative variance & 0.23 & 0.43 & 0.63 & 0.72 & 0.78 \\
\hline
\end{tabular}

Next, we repeated the PCA with the OO-approach (i.e., pixel means of the visually interpreted segments of fluvial forms). In this case, we also had to exclude variables due to low communality, although only three of them were excluded (MxEMs, DiurnAH, PlanCurv), and the explained total variance was $86 \%$ with good fit $($ RMSR $=0.04)($ Table 3$)$.

Table 3. Principal components (PC1-5) of the PCA conducted on all variables of the segments (mean pixel values of fluvial forms).

\begin{tabular}{cccccc}
\hline Statistic & PC1 & PC2 & PC3 & PC4 & PC5 \\
\hline SS loadings & 20.29 & 19.02 & 7.38 & 4.44 & 2.35 \\
Proportion variance & 0.33 & 0.31 & 0.12 & 0.07 & 0.04 \\
Cumulative variance & 0.33 & 0.63 & 0.75 & 0.82 & 0.86 \\
\hline
\end{tabular}

The correlation plot (Figure 3) also showed that geomorphometric variables formed highly correlating groups, but these groups usually contained 6-7 variables (i.e., corresponding to PCs of PCA). Cronbach's alpha indicated poor reliability $(<0.001)$, but the omission of FlodO, MxEMs, Aspct, CatchA, ConvI, ModCA and ValDpth resulted in a better outcome of 0.690 . This value is still low; it should usually be above 0.8 . 


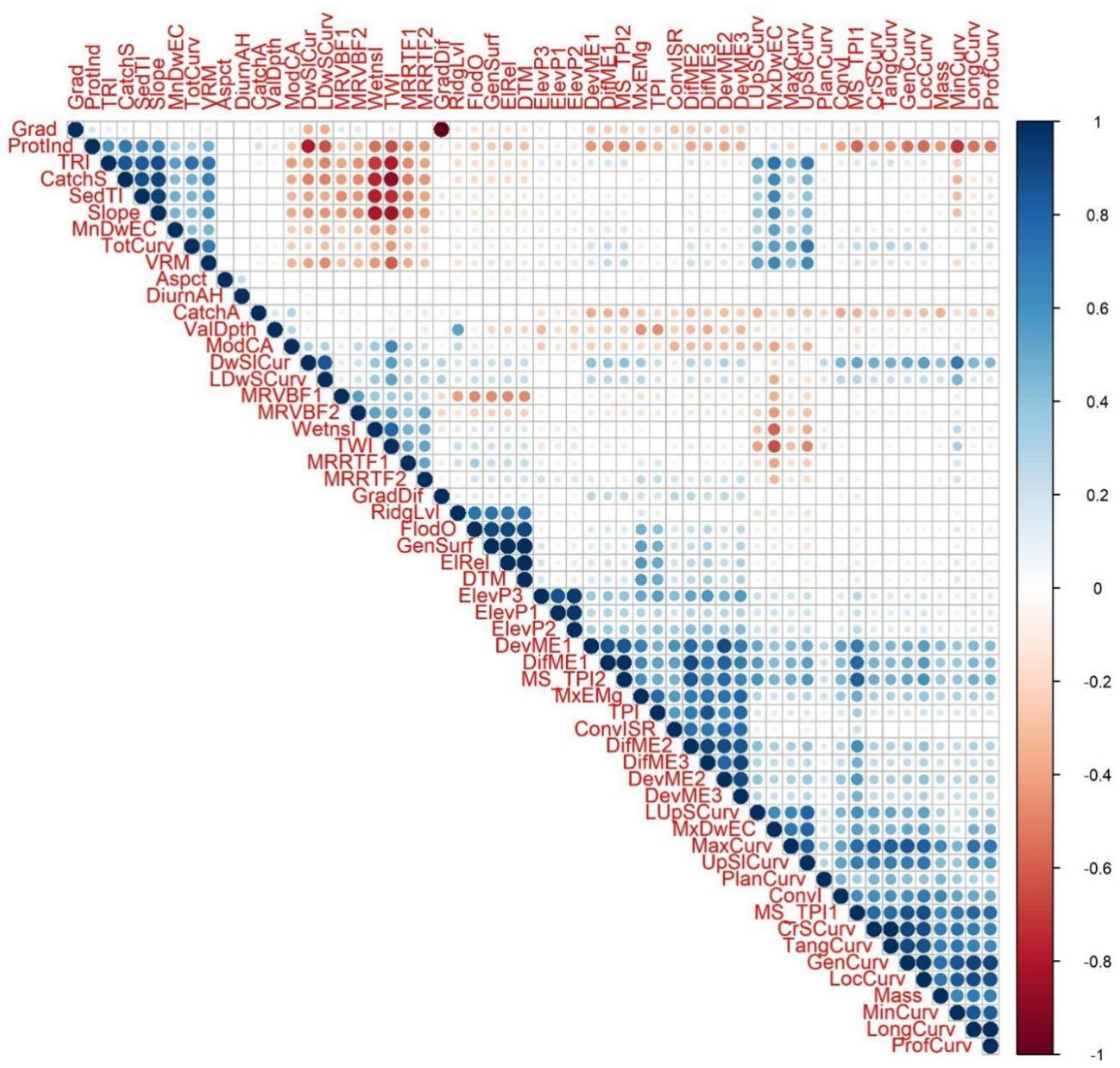

Figure 3. Correlation plot of geomorphometric variables.

RFE revealed the most important variables, and according to the different numbers of data, and the different types of data collection (large number of cases vs. fewer aggregated data), the ranks were different:

1. PB-approach: maximum $\mathrm{OA}$ had been reached with 20 variables (Figure 4) GenSurf $>$ DTM $>$ ElRel $>$ FlodO $>$ TPI $>$ MRVBF1 $>$ DevME3 $>$ DifME3 $>$ ValDpth $>$ RidgLvl $>$ ConvISR $>$ ElevP3 $>$ MxEMg $>$ DifME2 $>$ ElevP2 $>$ DevME2 $>$ MRRTF1 $>$ VRM $>$ MRRTF2 $>$ SedTI.

2. OO-approach: maximum $\mathrm{OA}$ had been reached with 13 variables (Figure 5) MRVBF1 $>$ MorfFeat $>$ MS_TPI2 $>$ ConvISR $>$ DifME1 $>$ DevME1 $>$ FlodO $>$ ConvI $>$ MS_TPI1 $>$ ElRel $>$ LocCurv>DTM $>$ GenSurf. 


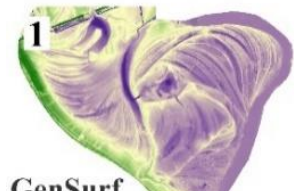

GenSurf

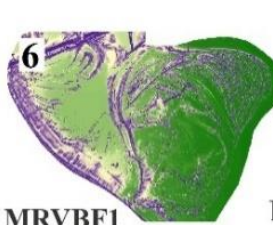

MRVBF1

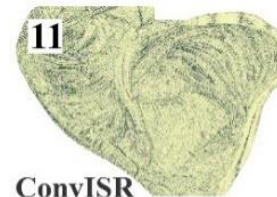

ConvISR

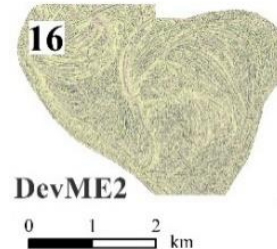

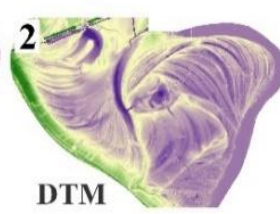
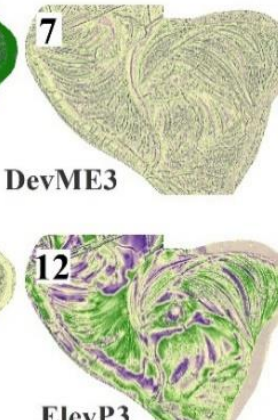

ElevP3

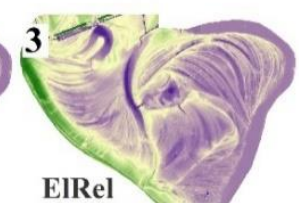

EIRel
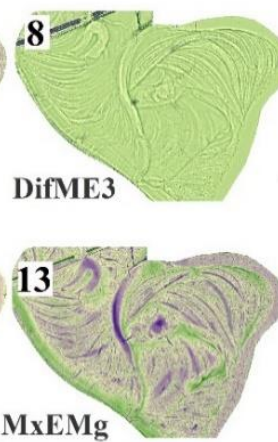

MxEMg
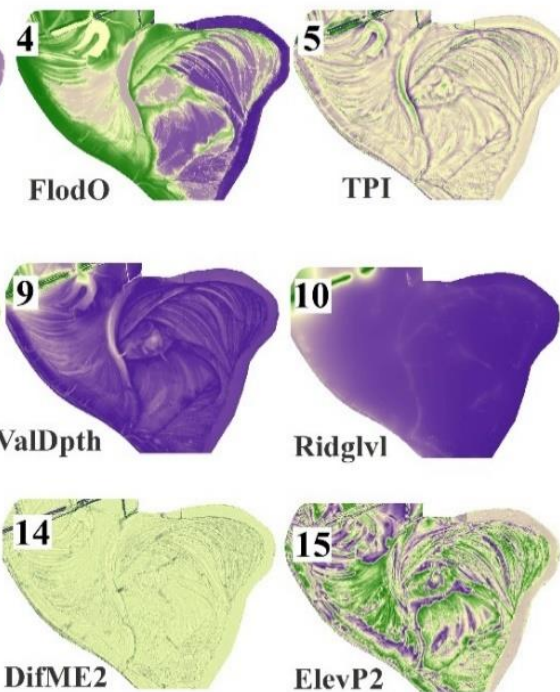

DifME2
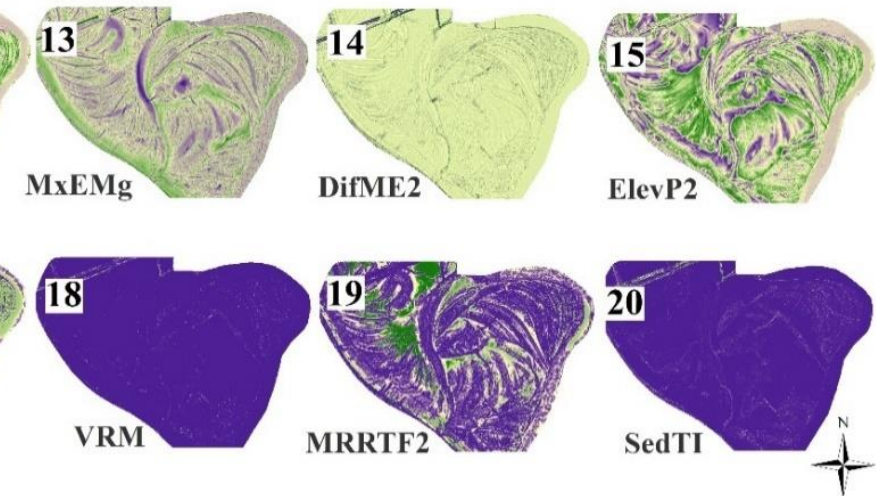

Figure 4. The variables that contributed to reaching the maximum OA in the pixel-based-approach.
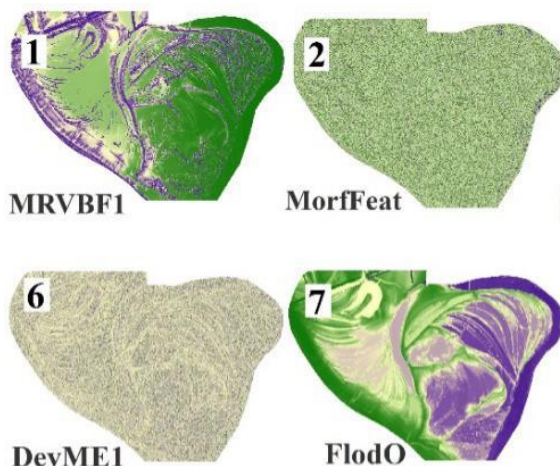

FlodO

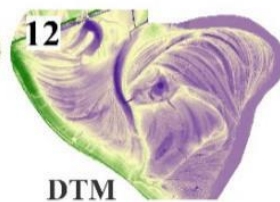

LocCurv

0

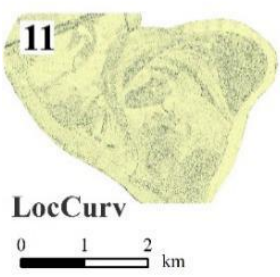

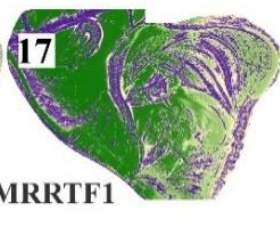

Figure 5. The variables that contributed to reaching the maximum OA in the object-oriented-approach.

A stability analysis of the variables of the PB-approach according to the RFE showed that the number of optimal variables (i.e., ensuring the largest OA) varied between 11 and 20, and the OAs varied between $78.5 \%$ and $81.1 \%$ (Figure 6). GenSurf was the first in the rank order in eight cases out of the 11 repetitions, ElRel was the second in eight cases, DTM was the third in seven cases, FlodO was the fourth in eight cases and TPI was the fifth in five cases; all other rank places were mixed with different indices. Regarding the first ten variables, GenSurf, ElRel, DTM, FlodO, TPI, DevMe3, DifME3 
and ValDpth were stable elements of the ranking, MRVBF1 was in the list in nine cases, and the rest of the places consisted of other morphometric indices.

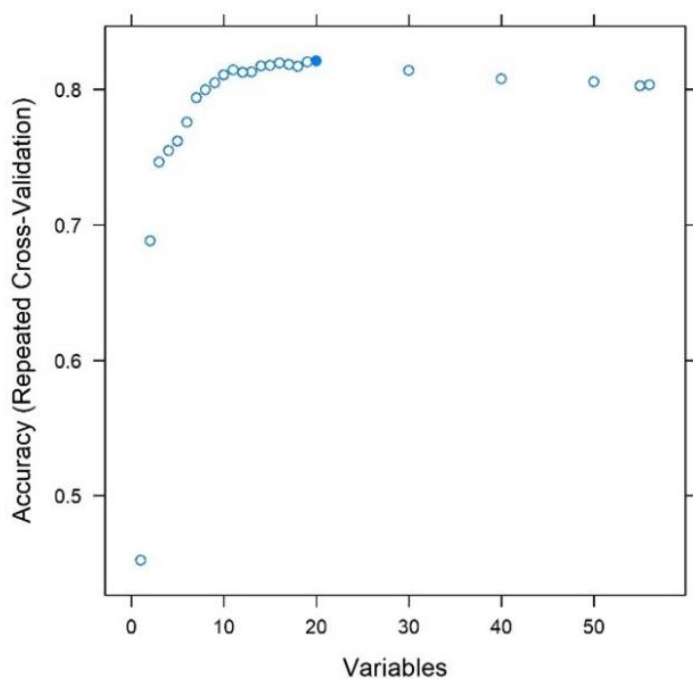

(a)

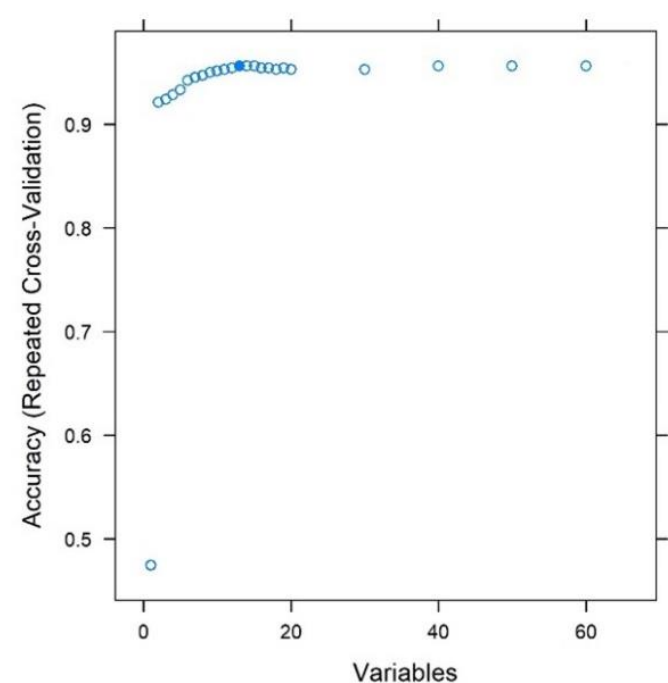

(b)

Figure 6. Overall accuracy and number of variables according to the Recursive Feature Elimination variable selection method in pixel-based (a) and object-oriented (b) methods (10-fold cross-validation with 3 repetitions, i.e., 30 models; •: highest $\mathrm{OA})$.

The rank order of the variables was different for the OO-approach: the optimal number of variables varied between 10 and 60 , with almost the same OAs between $95.2 \%$ and $95.7 \%$. The most important variable was MRVBF1, which was the first in the rank order in 11 cases of the 11 repetitions. The second in the list was MorfFeat in 11 cases, the third was ConvISR in 5 cases, the fifth was MS_TPI2 in 8 cases and the sixth was DevME1 in 11 cases. From the seventh place in the rank, there was no dominant variable.

\subsection{Overall Accuracies of RF Classifications}

\subsubsection{Pixel-Based Classification}

As a first step, we involved all of the 61 variables and determined its overall accuracy: its $80.7 \%$ median OA indicated an efficient outcome (Figure 7a). Reducing the number of variables caused a slight decrease in OAs, but the rank order by OAs did not follow the number of variables. Differences in the OA-medians were slight and ranged between $79.7 \%$ (25 variables) and $76.1 \%$ (four variables). The model with four geomorphometric indices, GenSurf, ElRel, DTM and FlodO, was only $4.6 \%$ worse in the prediction than when 61 variables were used (Figures $7 \mathrm{a}$ and $8 \mathrm{~b}$ ). Furthermore, 11 variables resulted in the fourth best result (78.3\%), and the optimal 20 variables according to the RFE produced an OA of $79.5 \%$, which is only $1.1 \%$ worse than the model run with 61 variables. Finally, we tested the efficiency of the PCA-model, which was the fourth worst model (with a median of $74.2 \%$ ), and worse than using four variables. However, there was a threshold in the decrease in OAs at three variables: the decreases in the OAs changed from $<1 \%$ to $15 \%$. 


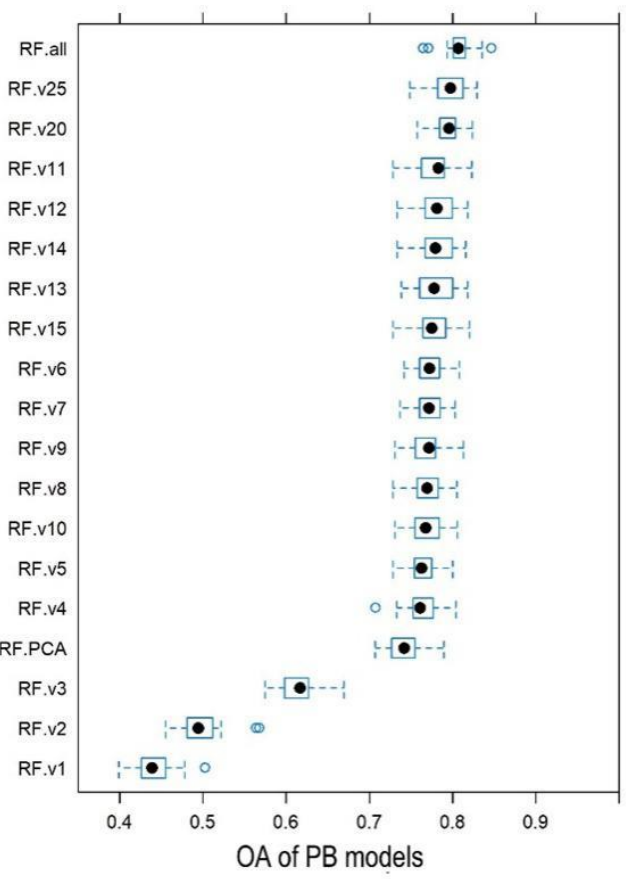

(a)

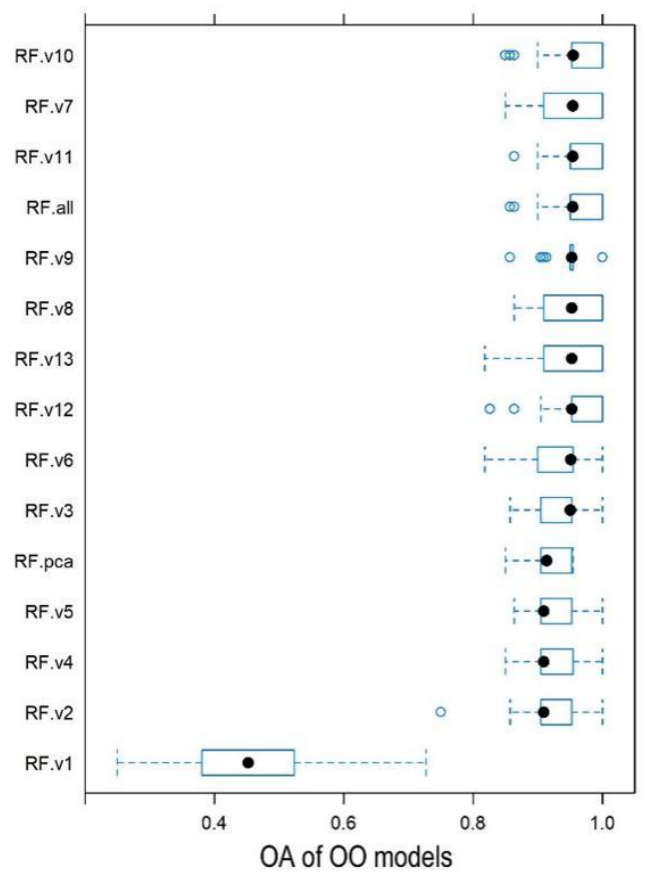

(b)

Figure 7. Classification accuracies of different variable sets using a 10-fold cross-validation with 3 repetitions (i.e., 30 models; (a) PB: pixel-based approach; (b) OO: object-oriented approach).

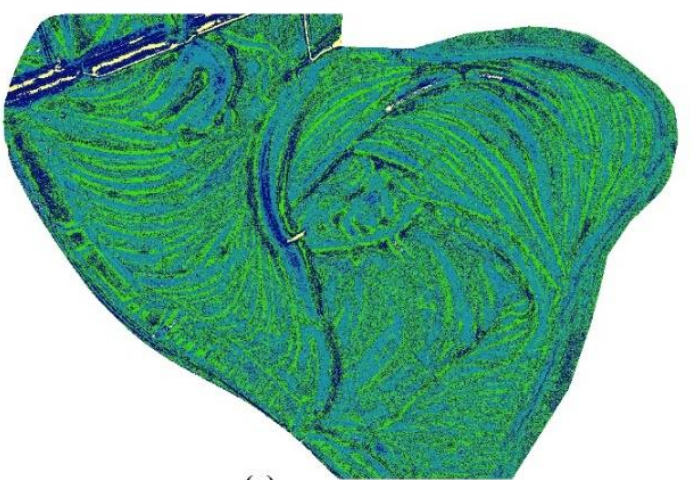

(a)

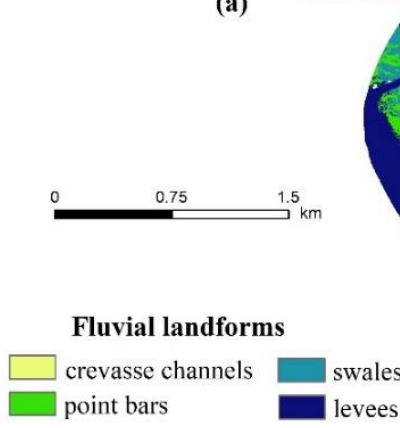

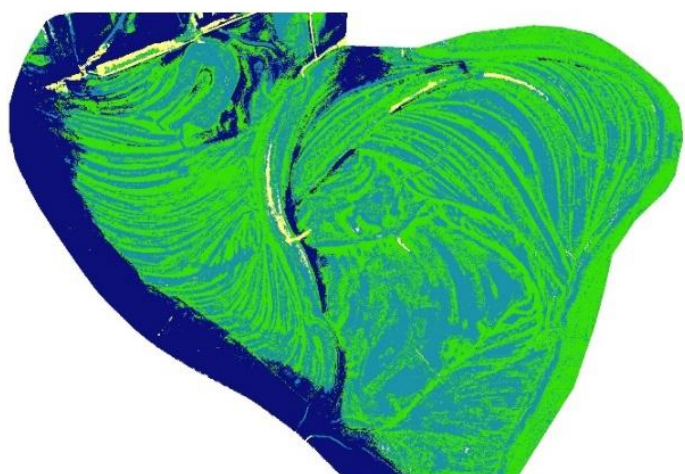

(b)

(c)

Figure 8. Landform map of the floodplain using 2 (a) 4 (b) and 20 (c) variables based on the pixel-based approach.

Visualizing the classifications revealed that the 2-variable solution relevantly underestimated the swales and had a high proportion of salt-and-pepper errors (Figure 8a). The appearance of the 4- and 
20-variable versions showed clarified maps with only a small proportion of salt-and-pepper errors. Both versions had errors in the southern part of the study area; swales had been over-represented. However, this area consisted of lakes (Kis-Morotva Lake, Kis-Pap Lake and Nagy-Pap Lake) and a floodplain depression of an irregular shape. Further sources of misclassifications were also outside the areas of interest; these were oxbow lakes at the northern part (Sulymos Lake) and on the eastern border (Nagy-Morotva Lake). Generally, the 20-variable solution reflected the geomorphology in an acceptable way and all larger errors were any of the forms we intended to identify.

\subsubsection{Object-Oriented Classification}

We applied the same procedure in OO-based classifications, too, and the result was different: the best OA belonged to the model of 10 -variables (95.4\%) (Figure $7 \mathrm{~b}$ ), which is almost $15 \%$ better than in the PB-approach. Another difference is that the optimal number of variables was 13 according to the RFE variable selection, but it was only the seventh best model in the list. We can discriminate three groups by the OAs: in the first group, the OAs were between $95.4 \%$ and $95.0 \%$, in the second group between $91.3 \%$ and $90.9 \%$, and third group consisted of only one model (with one variable) with an OA of $45.2 \%$. The first three variables, MRVBF1 $>$ MorfFeat $>$ MS_TPI2, ensured a relatively high $(95.0 \%)$ accuracy. Although the interquartile ranges were larger than in the PB-approach, even the minimums were $\sim 10 \%$ higher in the OO-models.

Maps of the OO-approach, i.e., the classified polygons, did not have large differences regarding the number of involved variables (Figure 9). Related to the 13-variable model, the 2-variable model had only some misclassifications, the two models were very similar, and most of the differences were of swales wrongly classified as crevasse channels. Furthermore, we found swales classified as point bars, and a point bar classified as a levee, but the geomorphic characteristics had been well represented in spite of the model errors.
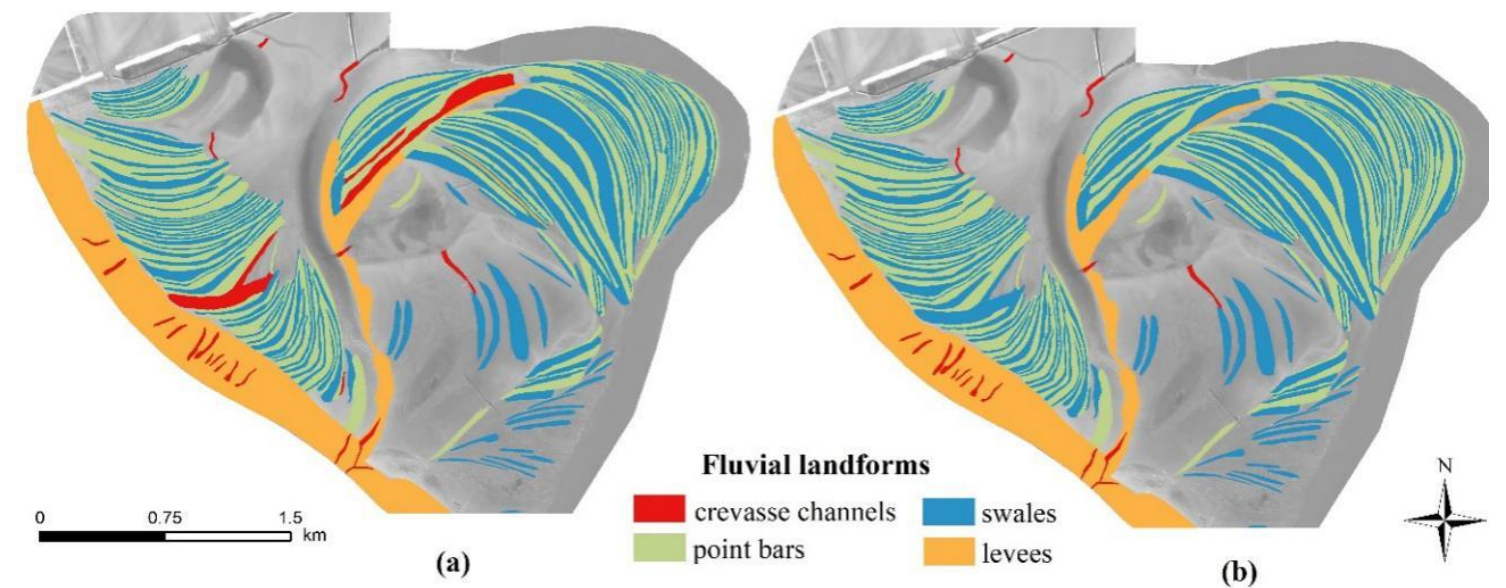

Figure 9. Landform map of the floodplain using 2 (a) and 13 (b) variables based on the object-oriented approach.

\subsection{Class Level Probabilities of Classifications}

The highest probabilities usually belonged to crevasse channels and point bars, while the lowest belonged to swales (Figure 10). However, this result is misleading, because F1-values indicated that the lowest accuracies were experienced in crevasse channels $(<20 \%)$, and the swales and point bars had the greatest accuracy (60-70\%; Figure 11). Regarding the number of variables, using 20 variables should have resulted in the most efficient model with the PB-approach according to the RFE, and this was true for the OA values ( 25 variables was only $0.2 \%$ better; Figure 6 ), but in the case of class level probabilities, the highest numbers were experienced with the 8-10-variable models, which were also efficient with the F1-values (Figure 11). 


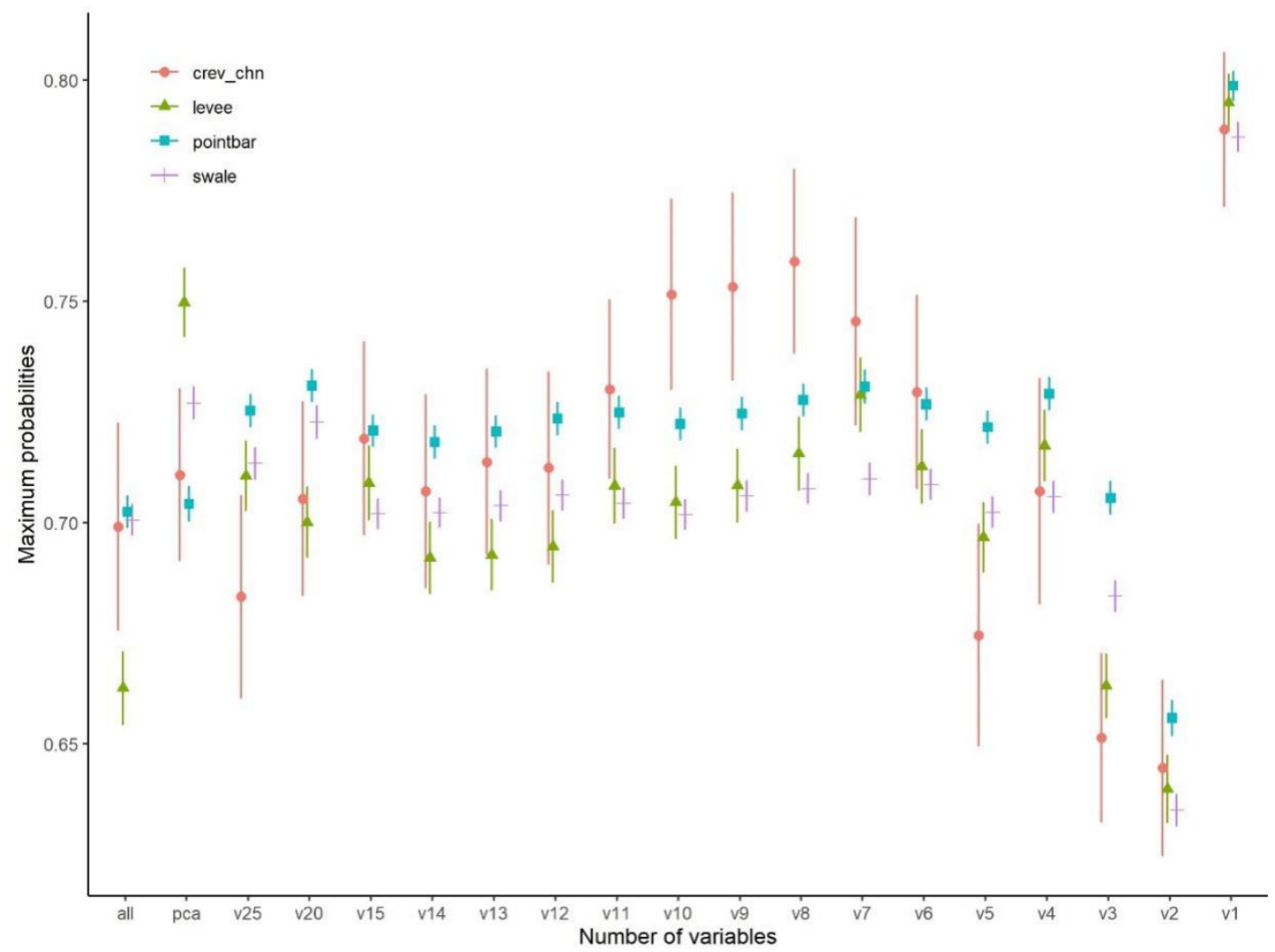

Figure 10. Maximum probabilities of PB-classifications by fluvial forms in the function of the number of variables (mean \pm standard error; $v$ : number of variables).

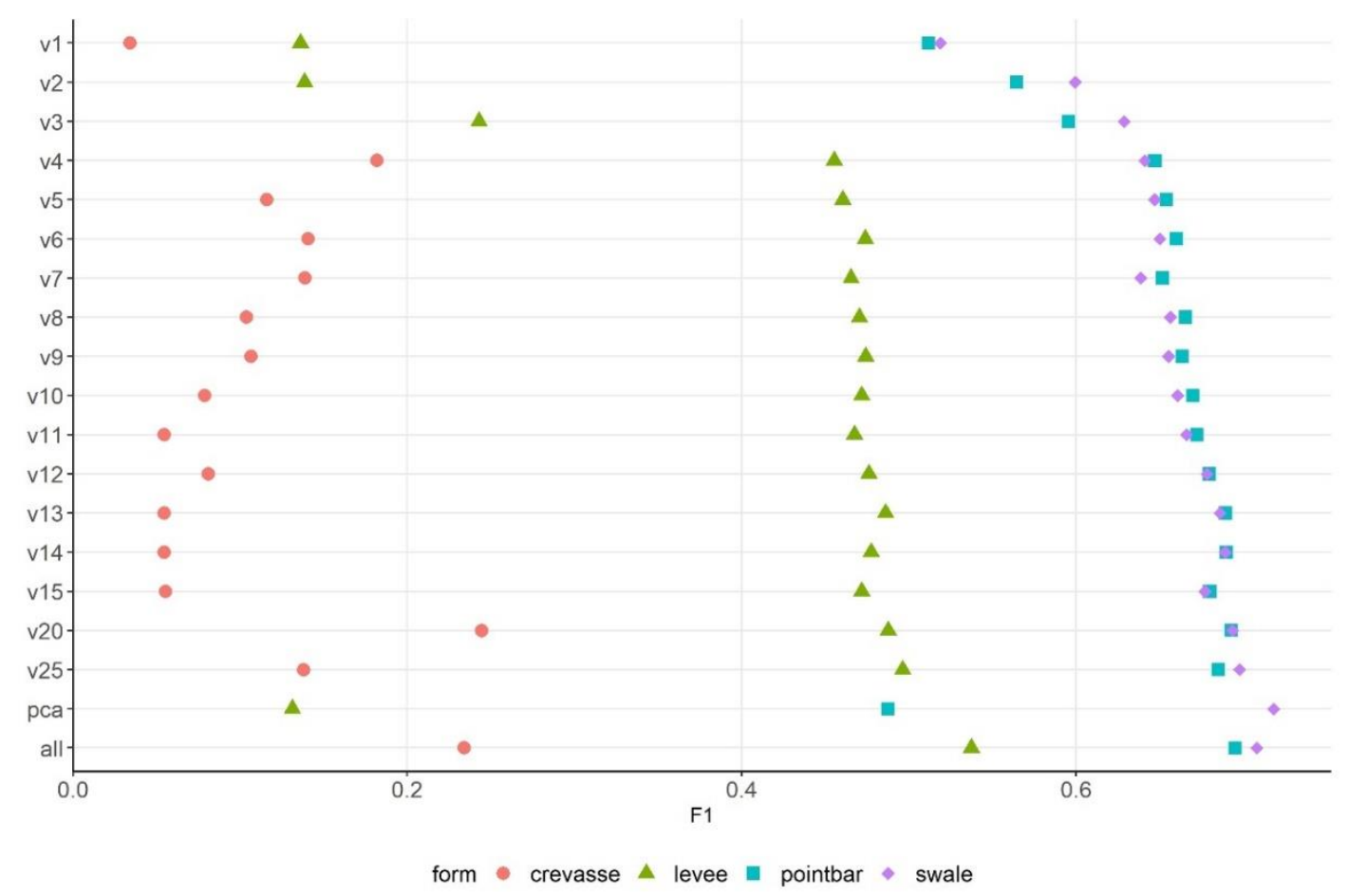

Figure 11. F1 class level metric of PB-classifications by fluvial forms in the function of the number of variables (v: number of variables). 
Visualized maximum probability values (Figure 12) correspondent with the maps, but this was a natural phenomenon as the result of the classification, and the probability had been calculated with the same algorithm and settings. However, combining this information with the mean values of the landform classes (Figure 10), we were able to justify that the spatial distribution of the different values of probability provided the landform map itself.

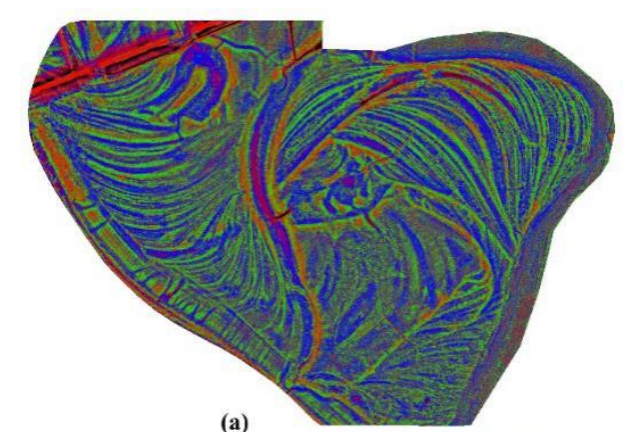

(a)

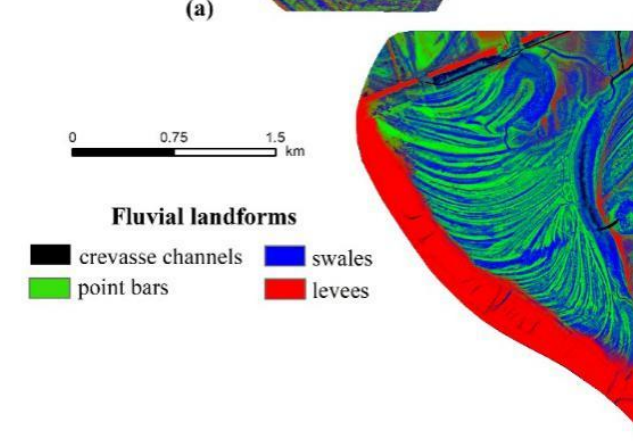

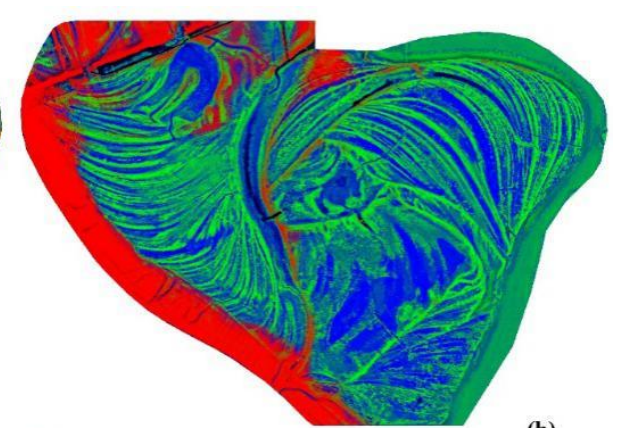

(b)

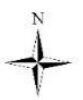

Figure 12. Maximum probability values of landforms calculated by the Random Forest classifier (i.e., these values belonged to the classified pixels; (a): 2-variable, (b): 4-variable, (c): 20-variable solutions). We used a composite to visualize the results (red band: levees; green band: point bar; blue band: swale; and the black color was the crevasse channel).

In the OO-approach, probabilities were higher, usually above $80 \%$, and the levees had the lowest and the point bars the highest values (Figure 13). Although the 13-variable model did not result in better classification probabilities for the fluvial forms, the F1-values showed that the best class level performance belonged to this model (Figure 14). We also have to note that the performance of models conducted with 10-11-12-13 variables was almost the same according to the F1. 


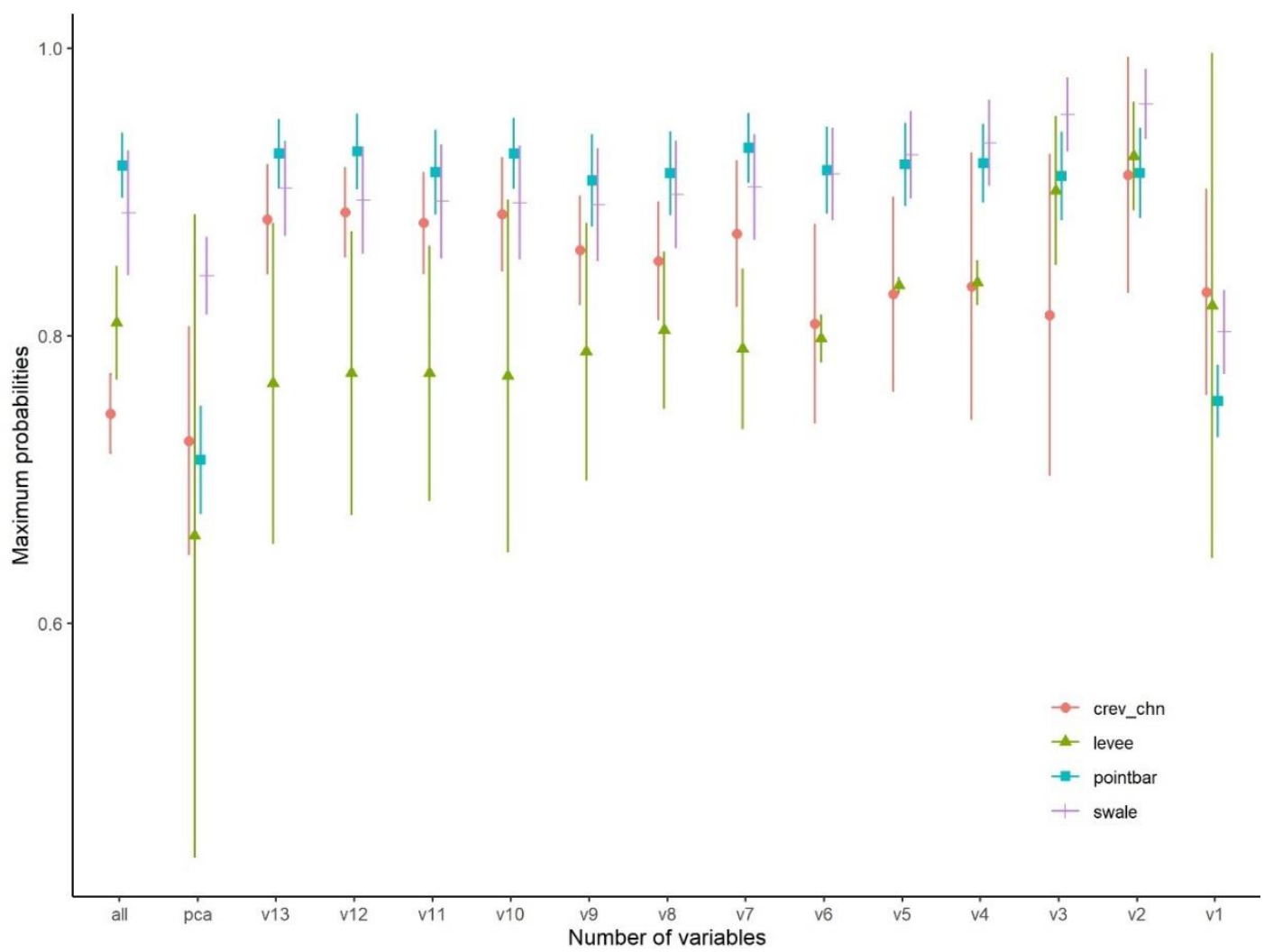

Figure 13. Maximum probabilities of OO-classifications by fluvial forms in the function of the number of variables (mean \pm standard error; v: number of variables).

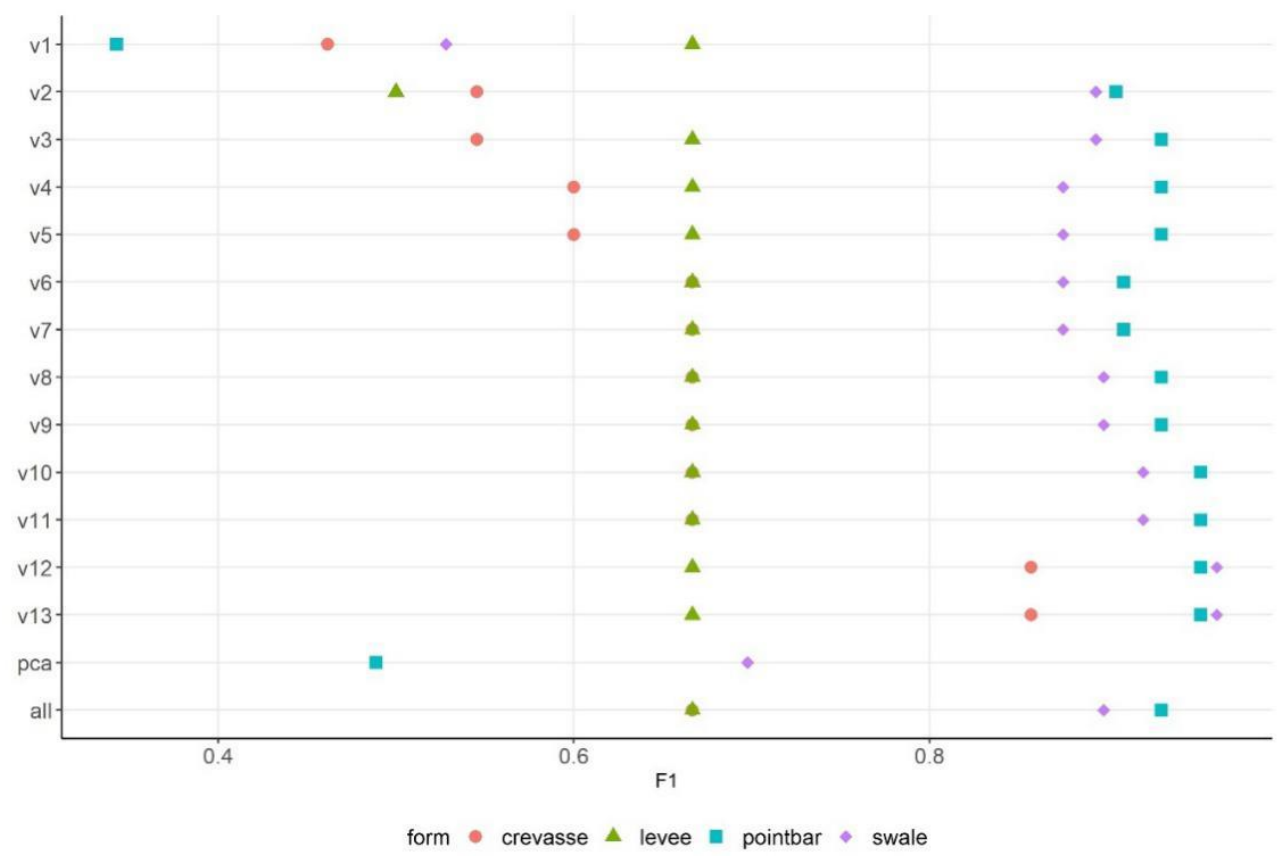

Figure 14. F1 class level metric of OO-classifications by fluvial forms in the function of the number of variables (v: number of variables). 


\subsection{Spatial Uncertainty Issues}

Spatial uncertainty analysis, as reflected in different realizations of classifications, also pointed to the fact that even a high classification performance showed different results, i.e., repetitions resulted in different spatial outcomes (Figure 15). According to the 10 repetitions, the lowest proportion of differing realizations was associated with the levees (mean: $2.8 \%$ ), and the point bars and swales had the largest proportion with almost the same values (mean: 6.9 and 6.5\%, respectively). The uncertainty was the highest with the 2-variable models, and became stable when more than 10 variables were involved, but this did not mean lower values: point bars and swales had $1 \%$ more uncertainty with 10 variables (increasing from 6.1 to $7.1 \%$ ).

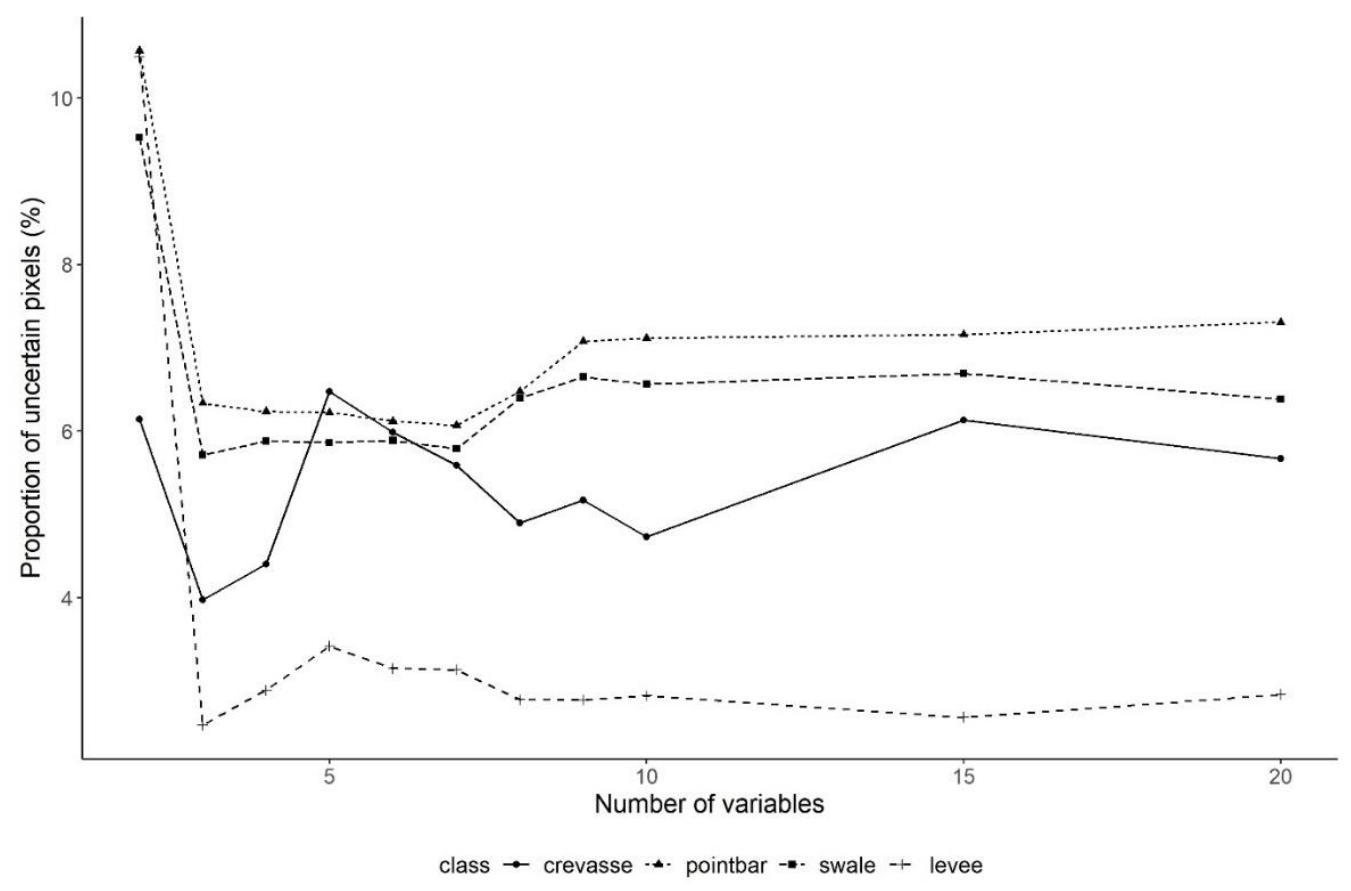

Figure 15. Proportion of spatially uncertain pixels (classified into different types) related to the total number of pixels by fluvial forms, based on 10 repetitions.

\subsection{Result of Overfitting Analysis}

Overfitting, i.e., the effect of the number of variables on the OA values, was not obvious: the overfit difference was usually more than $12 \%$ above four variables for the PB-approach and $7 \%$ with the OO-approach (Figure 16). However, the peak of the PB-approach at 48 variables ( $26.6 \%$ difference) belonged to the model using the PCs of PCA, and as we pointed out, the explained variance of the PCA was not high (only 78\%). In the OO-approach, the explained variance of the PCA of 52 variables was higher $(86 \%)$ with a better model fit, and the difference was one of the smallest. The analysis revealed that using all variables did not cause a larger difference between the OAs of training and testing datasets than using only five variables. In the OO-approach, the difference was the smallest with the 1-variable and the 13-variable models. 


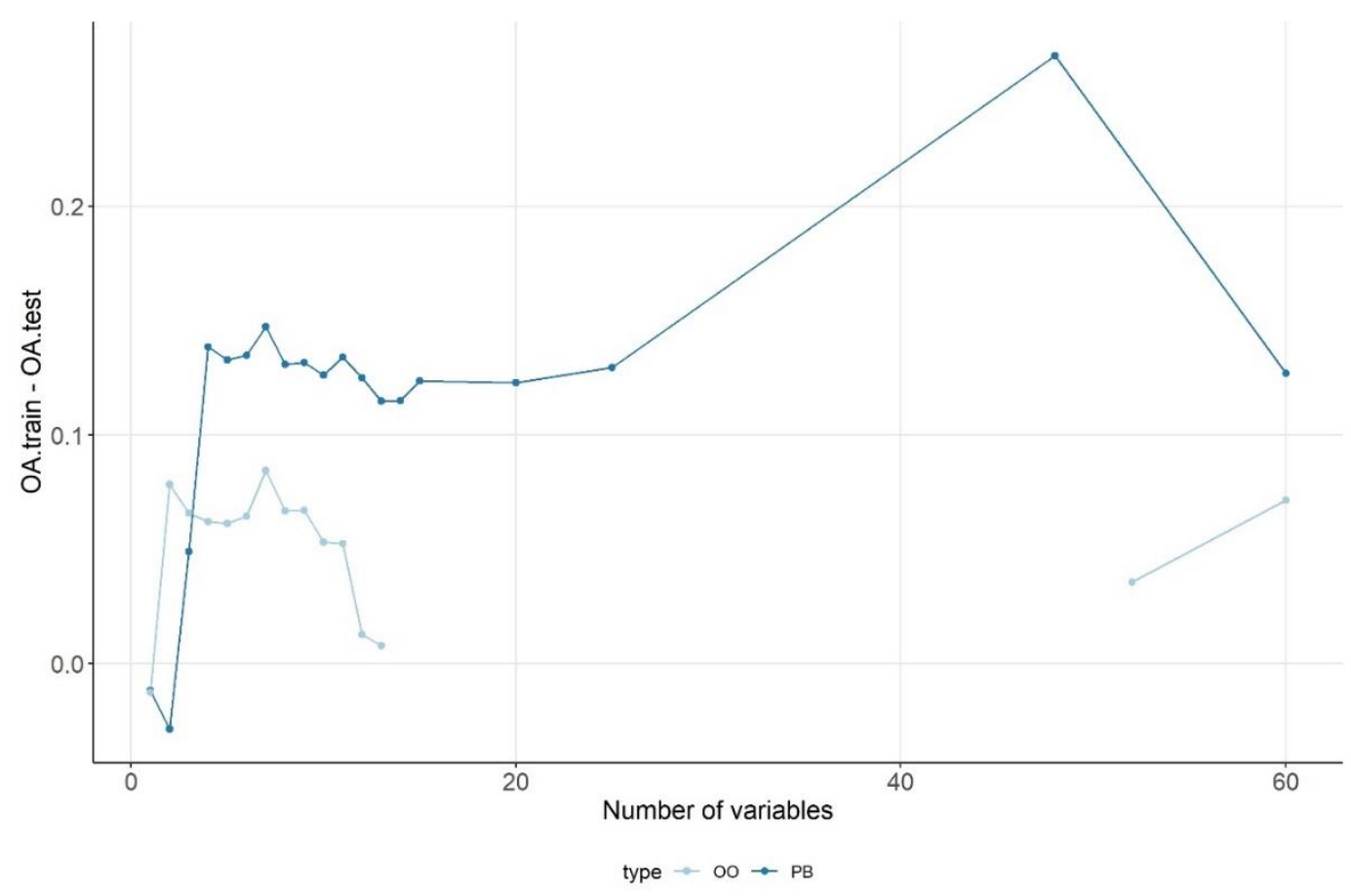

Figure 16. Change in overfitting and the number of variables in object-based $(\mathrm{OO})$ and pixel-based (PB) approaches.

GLM models also indicated that F1 values were determined by the fluvial forms and the role of the number of variables was not significant, and also had a low effect size (Tables 4 and 5). Accordingly, fluvial forms had characteristically higher or lower F1 values, i.e., the number of variables did not improve the class level indices in a relevant way.

Table 4. Result of GLM, based on the PB-approach (dependent variable: F1).

\begin{tabular}{cccccc}
\hline Parameters & SS & df & F & $p$ & $\boldsymbol{w}^{2}$ \\
\hline Model & 3.3757 & 4 & 122.18 & $<0.001$ & 0.869 \\
Fluvial form & 3.3436 & 3 & 161.36 & $<0.001$ & 0.863 \\
Number of variables & 0.023 & 1 & 3.33 & 0.072 & 0.004 \\
Residuals & 0.4697 & 68 & & & \\
Total & 3.8454 & 72 & & & \\
\hline
\end{tabular}

Table 5. Result of GLM, based on the OO-approach.

\begin{tabular}{cccccc}
\hline Parameters & SS & df & F & $p$ & $\boldsymbol{w}^{2}$ \\
\hline Model & 0.7663 & 4 & 15.86 & $<0.001$ & 0.515 \\
Fluvial form & 0.7394 & 3 & 20.41 & $<0.001$ & 0.504 \\
Number of variables & 0.027 & 1 & 2.23 & 0.141 & 0.011 \\
Residuals & 0.6159 & 51 & & & \\
Total & 1.3823 & 55 & & & \\
\hline
\end{tabular}

\section{Discussion}

3D point clouds of LiDAR are considered to be the most efficient and powerful surveying method, which provides accurate data about the ground and objects' surface height, even in vegetated areas. However, this data type can have issues in areas where the terrain is flat, but the relative differences cause important changes in the environment. These areas include wetlands, floodplains, and salt-affected steppes where $0.1-0.2 \mathrm{~m}$ relative differences cause changes in the water supply, soil 
moisture or salt content. A better understanding of the geomorphology and the fluvial processes can help sustainable planning in these areas, and the LiDAR technology can be a promising tool for this.

\subsection{Object-Oriented and Pixel-Based Classifications}

The OO-approach provided 15-17\% better model performance for fluvial form identification than the PB-approach. The object-based and pixel-based comparisons usually proved that segments ensure better input data than pixels. The authors of [98] came to the same conclusion; they applied object-based "geons", i.e., homogenous regions, and pixels in the landslide susceptibility mapping and the approach using segments—-the geons—-provided the highest accuracy. Several other authors found the same results: [99] with hyperspectral data, [100] with Sentinel-2 images, [101,102] with ASTER images, and [103] with visible aerial imagery. We emphasized that our OO-based approach was not a classic segmentation of object-based image analysis (OBIA); our objects were fluvial forms interpreted by visual characteristics and field observations. Thus, in our case, one object meant a given fluvial form, with the sole exception of levees (there were too few forms: we divided up the existing ones to increase the cases). Similarly to the studies where OBIA was successful, our objects of fluvial forms were good basic units of the landscape, but the main difference from the OBIA lies in the interpretation: it needs expertise (the capability to identify the forms in aerial images, in digital terrain models and in the field); furthermore, it is time-consuming (depending on the extent), i.e., all objects in the area should be identified correctly; however, when it is completed, the geomorphological aspect is ready, too. Unlike segments that varied in shape as the pixel values changed, our objects covered all of the pixels that are characteristic of the classes. Accordingly, the mean pixel values of the raster layers of geomorphometric variables can regarded as the quantified measure of the separability of the forms. If classifications produce only a weak performance, we cannot expect a high degree of accuracy in the PB-approach. As our OO-based classifications provided about 95\% OA, this was the theoretical maximum for the PB-approach, too. The 78-80\% OA for the PB-approach was higher than using only the slope, aspect, terrain height and NDVI with two fluvial forms (71\% OA; [47]).

\subsection{Variable Selection, Number of Variables and the Issue of Overfit}

Variable selection is a key step to reduce the number of variables in order to decrease the chance of overfitting while preserving high classification accuracy. We ran several models with different variable sets and the number of variables, and the results showed that in the OO-approach, the OAs were $\sim 95 \%$, and in the PB-approach, $\sim 78 \%$. The highest OAs were obtained with the highest number of variables for the PB-approach, but in the OO-approach this was not entirely true: involving all variables only resulted in the fourth place (although it is also important that the difference among first three models was $<0.2 \%$ ). Accuracy assessment using the RKCV was $7 \%$ worse than testing with the training data, indicating serious overfitting. With the OO-approach, the smallest overfit was experienced with the 1-, 12 - and 13 -variables models $(1 \%, 1.2 \%$ and $0.8 \%$, respectively). The overfitting was $6-7 \%$ in all other models, regardless of the number of variables, and even when using $2-9$ variables. In the PB-approach, the overfitting was higher, at $11-12 \%$, and the lowest values were observed with 1-3 variables. However, 1-3 variables produced a poor model performance, too; thus the lowest overfit values were not useful in selecting the best model.

An uncommon phenomenon was experienced with the PCA: application of PCs usually results in higher model performance, as has been proven in different studies [104-107]. However, in this case, the PCA was not a successful alternative. According to the analysis of correlation structure, several potentially useful metrics should be omitted based on the communality and the item-related Cronbach's $\alpha$. For example, FlodO, ConvI and ValDpth were important predictors in the classification, but if we insist on the correlation-related dimension reduction, we have to miss them. The reason was that the correlation structure was not optimal, and the variables were geomorphometric indices and not bands of a hyperspectral sensor, where there is a high level of correlation between the bands. The authors of [108] used PCA with geomorphometric variables in watershed prioritization, but they 
used watershed parameters, which resulted in a better correlation structure. The authors of [109] used PCA to reduce 230 terrain attributes to 67 , and they concluded that five metrics were enough to explain $51 \%$ of the total variance. In our case, we were not able to delineate this reduction, but the RFE as a feature selection method was appropriate to find the most important variables.

RFE provided a list of 13-20 variables from the possible 61, but the structure, i.e., the variables that make the list, varied. RFE was run with the RF algorithm, which uses several decision trees of bootstrapped samples, and all model runs can provide different results. Our experiment with 11 randomly selected datasets from the 5000 pixels and 265 forms showed that the OO and PB-approaches had different variables that contribute to the highest OAs. Furthermore, there were important variables, with relevant contributions in all repetitions. Our third observation was that although the variable sets could differ in the repetitions, the OAs obtained were the same in 1-2\% variations. Accordingly, if there are many variables, there are different variable sets, which ensure more or less the same result. The most important geomorphometric indices were GenSurf, ElRel, DTM, FlodO, and TPI for the PB-approach, and MRVBF1, MorfFeat, ConvISR, MS_TPI2, and DevME1 for the OO-approach. In the first most important ten variables we find overlaps, but with different settings, i.e.,: with DevME and DifME, although MRVBF was the same regarding the ranks. Differences in the importance were normal, because the number of the data (1000 vs. 265) and the characteristics of the data (pixel values vs. pixel means by forms) were also different. The authors of [110] pointed out that RFE is useful in reducing predictor numbers; thus, machine and deep learning algorithms can be faster without variables that make a small contribution. We also experienced that RF models were trained in a shorter time, and the model accuracy was only slightly (1-2\%) lower; moreover, in the OO-approach, omitting irrelevant predictors, and with only 10-13 variables, the model became $\sim 1 \%$ better.

DTM (absolute terrain height) should have been efficient alone, but as the terrain had a slight change from the river to the dyke, and from the North to South, thus, swales and point bars can have the same height in the area. Accordingly, the most efficient metrics were able to reflect the specific characteristics of fluvial forms, i.e., the shapes, convexity-concavity, and relative situation of the forms. Efficient variables considered the relative differences (based on minimums and maximums) of the neighboring areas; furthermore, the convergence-divergence, GenSurf, Elrel, FlodO, MRVBF1 and ConvISR were important both for PB and OO-approaches, while DevME and DifME were also important but with different settings: the larger kernel window (with 16 and 32 neighboring pixels) were efficient for the PB-approach and the smaller kernel (8 neighbors) had large importance for the OO-approach. Finding the right class of a single pixel requires larger neighboring area, while with the $\mathrm{OO}$-approach values belonging to objects are means of the given polygon; therefore, larger kernels mean double averaging and do not help the classification.

\subsection{Uncertainty}

We measured the uncertainty in different ways, and the results were contradictory. The highest probability was associated with the classification, and highest values indicated that the decision regarding the classification was made in a straight or an ambiguous way, e.g., if the given probabilities varied, for example $0.90,0.05,0.05,0.00$, this meant that the classification identified the first class as $90 \%$, but if this occurred for another form the values were $0.40,0.35,0.25,0.10$, which meant that there was only a $5 \%$ difference between the first and second classes. Based on this, we expected that higher probabilities would cause better classification accuracy on a class level, but there was no connection between the mean probabilities of fluvial forms and the F1s. Moreover, there were contradictions in the PB-approach; the correlation was 0.14 with the highest probabilities associated with the crevasse channels, whilst the F1s were the lowest (even $<10 \%$ ). Although the results were more similar with the OO-approach, the correlation was 0.74 , and contradictions were also found (crevasse channels also had high values in some cases with low F1 values). Nevertheless, probability values reflected the spatial distribution of the landforms: all forms can be delineated based on the maximum probability of the 
pixels. This means that the maximum values differed by class, and these values were characteristic for all pixels of a given class. However, this value did not correspond with accuracy.

Spatial uncertainty analysis also produced similar results: the proportion of uncertain pixels was the highest for swales and point bars, and the lowest values occurred with the levees; meanwhile, the class level F1s showed the opposite result: swales and point bars had the highest class level accuracy. Considering the dominance of these two forms in the area, there is also a higher chance of misclassifying them. Point bars and swales have similar shapes and the main difference between them is that swales are concave while point bars are convex forms [47]. Swales are shallow and elongated depressions with varying water cover or at least higher soil moisture, the vegetation is denser, and tussocks (Carex species) form a naturally uneven surface. Thus, considering that the terrain height has a tendency to increase from the river to the dykes, all swales differ in extent, water cover, vegetation cover, and absolute height above sea level. Point bars can have the same terrain height as swales and in certain locations (i.e., lower point bars between higher point bars) and at certain time can be covered by water; thus, they can also have denser vegetation related to those in a higher terrain position $[50,111]$. Although these forms can be discriminated easily with visual interpretation, and can be identified in the field by geomorphologists, due to the large number of forms combined with the similarities, semi-automatic misclassification between these two forms can be regarded as normal.

All classifications have errors, and similar features are hard to discriminate. The fluvial forms of a floodplain have similar geomorphometric properties; thus, even with the most accurate aerial LiDAR-based DTMs, classifications cannot be accurate. Using the objects' outlines and calculating the mean pixel values by raster layers (i.e., the OO-approach), very accurate $95 \%$ models can be obtained, but this supposes that there is a properly interpreted map of the morphological forms. However, the accuracy of the PB-approach was also acceptable, with an OA of $78 \%$, considering that these investigated forms were similar from many perspectives. This research highlighted the importance of variable selection, and the specific characteristics of the models. We hypothesized that a larger number of variables increases the $\mathrm{OA}$ and decreases the uncertainty of the classifications, but the results were ambiguous: both the classification probabilities calculated by the RF algorithm, and the uncertainties calculated from the 10 repetitions of the classification maps, showed contradictory outcomes compared to the F1 as a class level accuracy metric.

\section{Conclusions}

We aimed to reveal the most important morphometric variables of fluvial form identification and to quantify the level of uncertainty and overfitting as a function of the number of variables. We found the following results:

1. A large number of morphometric variables can be used efficiently in the identification of levees, crevasse channels, point bars and swales. However, a larger number of variables did not ensure a relevantly better model performance.

2. RFE, as a variable selection technique, helped to find the fewest variables making the largest contribution to obtain the grates' accuracy. Our main finding was that the selected variable set can change by model runs; the maximum OAs were almost the same. Although the variables were not the same in the repeatedly conducted models, we were able to identify the most frequent ones. Involving four variables in the case of the PB-approach and two variables in the case of the OO-approach provided sufficient accuracy, and the errors did not differ relevantly from the maximum number of geomorphometric indices.

3. OO and PB-approaches performed differently: the object-oriented approach was more successful with $95 \%$ OA, while the $78 \%$ OA of the pixel-based approach was a weaker performance; nevertheless, all the forms were identifiable despite the misclassifications.

4. The probability of the classifications and the pixel-based spatial uncertainty (as different classification outcomes for the same pixels) was not an appropriate tool to evaluate the classification efficiency, because the values were not in accordance with the class level accuracy metric (F1s). 
5. Overfitting was in accordance with the optimal number of variables: the lowest level of overfitting coincided with the high OAs of the optimal number of variables.

6. We emphasize that the most important variables (GenSurf, Elrel, FlodO, MRVBF1, ConvISR, DevME, DifME) ensured accurate models for fluvial forms, but the selection methodology was more important. Different aims and target geomorphological forms can also be identified with the help of geomorphometry after a careful variable selection.

The 78\% accuracy of the PB-approach can be regarded as acceptable, as the fluvial forms studied had similar characteristics. These results, including the methodological findings, can help the water management directorates to evaluate the floodplain from a flood-management perspective and to find common points with nature conservation planners, to preserve the most valuable habitats.

Author Contributions: Conceptualization, Z.C.S. and S.S.; methodology, Z.C.S., T.M. and S.S.; software, Z.C.S. and S.S.; validation, Z.C.S., S.S., and O.G.V.; formal analysis, Z.C.S. and G.N.; investigation, Z.C.S., S.S., and G.N.; resources, P.B., T.M., O.G.V. and L.T.-S.; data curation, P.B., T.M., S.S. and L.T.-S.; writing-original draft preparation, Z.C.S., S.S., T.M. and G.N.; writing—review and editing, Z.C.S., S.S., T.M., O.G.V., L.T.-S., P.B. and G.N.; visualization, Z.C.S., T.M. and S.S.; supervision, S.S.; funding acquisition, S.S. All authors have read and agreed to the published version of the manuscript.

Funding: This research was funded by the National Research, Development and Innovation Office (NKFIH) KH 130427 project.

Acknowledgments: We would like to thank to the Trans Tisza Water Directorate who provided the LiDAR point cloud for the input data of the analysis. Part of this research was carried out during the timeframe of an Erasmus+ Traineeship Program in Brno, Czech Republic. The TNN123457 project also contributed to this research.

Conflicts of Interest: The authors declare no conflict of interest.

\section{References}

1. Wolman, M.G.; Leopold, L.B. River Flood Plains: Some Observations On Their Formation (Physiographic and hydraulic studies of rivers). In Geological Survey Professional Paper 282-C; Pecora, W., Ed.; U.S. Government Printing Office: Washington, DC, USA, 1957; pp. 87-107.

2. Bridge, J.S.; Demicco, R.V. (Eds.) Earth Surface Processes, Landforms and Sediment. Deposits; Cambridge University Press: Cambridge, UK, 2008; ISBN 978-0-511-45522-3.

3. Bertalan, L.; Rodrigo-Comino, J.; Surian, N.; Šulc Michalková, M.; Kovács, Z.; Szabó, S.; Szabó, G.; Hooke, J. Detailed assessment of spatial and temporal variations in river channel changes and meander evolution as a preliminary work for effective floodplain management. The example of Sajó River, Hungary. J. Environ. Manag. 2019. [CrossRef]

4. Brierley, G.J.; Ferguson, R.J.; Woolfe, K.J. What is a fluvial levee? Sediment Geol. 1997, 114, 1-9. [CrossRef]

5. Palaseanu-Lovejoy, M.; Thatcher, C.A.; Barras, J.A. Levee crest elevation profiles derived from airborne lidar-based high resolution digital elevation models in south Louisiana. ISPRS J. Photogramm. Remote. Sens. 2014, 91, 114-126. [CrossRef]

6. Fodor, Z. Az ártéri gazdálkodás fokai a tisza mentén. In Proceedings of the Földrajzi Konferencia, Szeged, Hungary, 25-27 October 2001; pp. 1-10.

7. Bridge, J. (Ed.) Rivers and Floodplains_Forms, Processes and Sedimentary Record; Blackwell Science Ltd.: Oxford, UK, 2003; ISBN 978-0-632-06489-2.

8. Hickin, E.J. The development of meanders in natural river-channels. Am. J. Sci. 1974, 274, 414-442. [CrossRef]

9. Nanson, G.C. Point bar and floodplain formation of the meandering Beatton River, northeastern British Columbia, Canada. Sedimentology 1980, 27, 3-29. [CrossRef]

10. Allen, J.R. A review of the origin and characteristics of recent alluvial sediments. Sedimentology 1965, 5, 89-191. [CrossRef]

11. Vass, R. Ártérfejlödési Vizsgálatok Felsö-tiszai Mintaterületeken (Examination of Fluvial Development on Study Areas of Upper Tisza Region); Tóth könyvkereskedés és Kiadó Kft.: Nyíregyháza, Hungary, 2018; ISBN 978-615-00-1833-1.

12. Burchsted, D.; Daniels, M.; Wohl, E.E. Introduction to the special issue on discontinuity of fluvial systems. Geomorphology 2014, 205, 1-4. [CrossRef] 
13. Babka, B.; Futó, I.; Szabó, S. Seasonal evaporation cycle in oxbow lakes formed along the Tisza River in Hungary for flood control. Hydrol. Process. 2018, 32, 2009-2019. [CrossRef]

14. Tamás, M.; Farsang, A. Determination of heavy metal fractions in the sediments of oxbow lakes to detect the human impact on the fluvial system (Tisza River, SE Hungary). Hydrol. Earth Syst. Sci. Discuss. 2016, 1-16. [CrossRef]

15. Szabó, J.; Vass, R.; Tóth, C. Examination of fluvial development on study areas of Upper-Tisza region. Carpathian J. Earth Environ. Sci. 2012, 7, 241-253.

16. Kiss, T.; Amissah, G.J.; Fiala, K. Bank processes and revetment erosion of a large lowland river: Case study of the lower Tisza River, Hungary. Water 2019, 11, 1313. [CrossRef]

17. Nagy, J.; Kiss, T. Point-bar development under human impact: Case study on the Lower Tisza River, Hungary. Geogr. Pannonica 2020, 24, 1-12. [CrossRef]

18. Newson, M.D.; Newson, C.L. Geomorphology, ecology and river channel habitat: Mesoscale approaches to basin-scle chailenges. Prog. Phys. Geogr. 2000, 24, 195-217. [CrossRef]

19. Montgomery, D. Geomorphology, River Ecology, and Ecosystem Management. Geomorphic Process. Riverine Habitat 2001, 4, 247-253.

20. Newson, M.D. Geomorphological concepts and tools for sustainable river ecosystem management. Aquat Conserv. Mar. Freshw. Ecosyst. 2002, 12, 365-379. [CrossRef]

21. Ortmann-Ajkai, A.; Lóczy, D.; Gyenizse, P.; Pirkhoffer, E. Wetland habitat patches as ecological components of landscape memory in a highly modified floodplain. River Res. Appl. 2014, 30, 874-886. [CrossRef]

22. Bertalan, L.; Novák, T.J.; Németh, Z.; Rodrigo-Comino, J.; Kertész, Á.; Szabó, S. Issues of meander development: Land degradation or ecological value? The example of the Sajó River, Hungary. Water 2018, 10, 1613. [CrossRef]

23. Hohausová, E.; Jurajda, P. Restoration of a river backwater and its influence on fish assemblage. Czech J. Anim. Sci. 2005, 50, 473-482. [CrossRef]

24. Bornette, G.; Amoros, C.; Lamouroux, N. Aquatic plant diversity in riverine wetlands: The role of connectivity. Freshw. Biol. 1998, 39, 267-283. [CrossRef]

25. Thorndycraft, V.R.; Benito, G.; Gregory, K.J. Fluvial geomorphology: A perspective on current status and methods. Geomorphology 2008, 98, 2-12. [CrossRef]

26. French, J.R. Airborne LiDAR in support of geomorphological and hydraulic modelling. Earth Surf. Process. Landforms 2003, 28, 321-335. [CrossRef]

27. Barrile, V.; Bilotta, G.; Fotia, A. Analysis of hydraulic risk territories: Comparison between LIDAR and other different techniques for 3D modeling. WSEAS Trans. Environ. Dev. 2018, 14, 45-52.

28. Milan, D.J.; Heritage, G.L.; Hetherington, D. Application of a 3D laser scanner in the assesment of erosion and deposition volumes in a proglacial river. Earth Surf. Process. Landforms 2007, 32, 1657-1674. [CrossRef]

29. Carey, C.; Brown, T.; Challis, K.; Howard, A.; Cooper, A. Predictive modelling of multiperiod geoarchaeological resources at a river confluence: A case study from Trent-Soar, UK. Archaeol. Prospect. 2006, 13, 241-250. [CrossRef]

30. Alho, P.; Hyyppä, H.; Hyyppä, J. Consequence of DTM precision for flood hazard mapping: A case study in SW Finland. Nord. J. Surv. Real Estate Res. 2009, 6, 21-39.

31. Cook, A.; Merwade, V. Effect of topographic data, geometric configuration and modeling approach on flood inundation mapping. J. Hydrol. 2009, 377, 131-142. [CrossRef]

32. Charlton, M.E.; Large, A.R.G.; Fuller, I.C. Application of airborne lidar in river environments: The River Coquet, Northumberland, UK. Earth Surf. Process. Landforms 2003, 28, 299-306. [CrossRef]

33. Jones, A.F.; Brewer, P.A.; Johnstone, E.; Macklin, M.G. High-resolution interpretative geomorphological mapping of river valley environments using airborne LiDAR data. Earth Surf. Process. Landforms 2007, 32, 1574-1592. [CrossRef]

34. Hengl, T.; Reuter, H.I. (Eds.) Developments in Soil Science. Geomorphometry. Concepts, Software, Applications; Elsevier, B.V.: Oxford, UK, 2009; ISBN 9780123743459.

35. Pike, R.J.; Evans, I.S.; Hengl, T. Geomorphometry: A brief guide. In Developments in Soil Science; Hengl, T., Reuter, H.I., Eds.; Elsevier B.V.: Oxford, UK, 2009; Volume 33, pp. 3-30.

36. Otto, J.-C.; Prasicek, G.; Blöthe, J.; Schrott, L. GIS applications in geomorphology. In Comprehensive Geographic Information Systems; Huang, B., Ed.; Elsevier Inc.: Bonn, Germany, 2018; pp. 81-111. ISBN 9780128047934. 
37. Dikau, R. The application of a digital relief model to landform analysis in geomorphology. In Three Dimensional Applications in Geographical Information Systems; Taylor and Francis: London, UK, 1989; pp. 51-77.

38. Pike, R.J. Geomorphometry—diversity in quantitative surface analysis. Prog. Phys. Geogr. 2000, 24, 1-20. [CrossRef]

39. Györgyövics, K.; Kiss, T. Landscape metrics applied in geomorphology: Hierarchy and morphometric classes of sand dunes in inner Somogy, Hungary. Hungar. Geogr. Bull. 2016, 65, 271-282. [CrossRef]

40. Enyedi, P.; Pap, M.; Kovács, Z.; Takács-Szilágyi, L.; Szabó, S. Efficiency of local minima and GLM techniques in sinkhole extraction from a LiDAR-based terrain model. Int. J. Digit. Earth 2018, 1067-1082. [CrossRef]

41. Wilson, J.; Gallant, J. Digital terrain analysis. In Terrain Analysis: Principles and Applications; Wilson, J.P., Gallant, J.C., Eds.; John Wiley \& Sons, Inc.: Hoboken, NJ, USA, 2000; Volume 479, pp. 1-27. ISBN 0471321885.

42. Gruber, S.; Peckham, S. Land-surface parameters and objects in hydrology. In Developments in Soil Science; Hengl, T., Reuter, H.I., Eds.; Elsevier B.V.: Oxford, UK, 2009; Volume 33, pp. 171-194.

43. Del Val, M.; Iriarte, E.; Arriolabengoa, M.; Aranburu, A. An automated method to extract fluvial terraces from LIDAR based high resolution Digital Elevation Models: The Oiartzun valley, a case study in the Cantabrian Margin. Quat. Int. 2015, 364, 35-43. [CrossRef]

44. Dowling, T.P.F.; Spagnolo, M.; Möller, P. Morphometry and core type of streamlined bedforms in southern Sweden from high resolution LiDAR. Geomorphology 2015, 236, 54-63. [CrossRef]

45. Passalacqua, P.; Belmont, P.; Foufoula-Georgiou, E. Automatic geomorphic feature extraction from lidar in flat and engineered landscapes. Water Resour. Res. 2012, 48, 1-18. [CrossRef]

46. Qian, T.; Shen, D.; Xi, C.; Chen, J.; Wang, J. Extracting farmland features from LiDAR-derived DEM for improving flood plain delineation. Water 2018, 10, 252. [CrossRef]

47. Szabó, Z.; Tóth, C.A.; Tomor, T.; Szabó, S. Airborne LiDAR point cloud in mapping of fluvial forms: A case study of a Hungarian floodplain. GIScience Remote. Sens. 2017, 54, 862-880. [CrossRef]

48. Hamar, J.; Sárkány-Kiss, A. (Eds.) The Upper Tisa Valley; Tisza Klub \& Liga Pro Europa: Szeged, Hungary, 1999.

49. Envirosense Hungary Kft. SH/2/6 — Swiss-Hungarian Programme edited by Envirosense Hungary Kft. Updating the Flood Protection Plans for Sections of the River Tisza under the Management of the Environmental and Water Management Directorate of the Tiszántúl Region and the North Hungarian Environment and Water Directorate; Envirosense Hungary Kft.: Debrecen, Hungary, 2013; p. 77.

50. Szabó, Z.; Tóth, C.A.; Holb, I.; Szabó, S. Aerial laser scanning data as a source of terrain modeling in a fluvial environment: Biasing factors of terrain height accuracy. Sensors 2020, 20, 2063. [CrossRef]

51. ESRI Arcgis Desktop: Release 10.5; Environmental Systems Research Institute: Redlands, CA, USA, 2014.

52. Conrad, O.; Bechtel, B.; Bock, M.; Dietrich, H.; Fischer, E.; Gerlitz, L.; Wehberg, J.; Wichmann, V.; Böhner, J. System for Automated Geoscientific Analyses (SAGA) v. 2.1.4. Geosci. Model. Dev. 2015, 8, 1991-2007. [CrossRef]

53. Lindsay, J.B. Whitebox GAT: A Case Study in Geomorphometric Analysis; Elsevier: Amsterdam, The Netherlands, 2016; Volume 95.

54. Wang, L.; Liu, H. An efficient method for identifying and filling surface depressions in digital elevation models for hydrologic analysis and modelling. Int. J. Geogr. Inf. Sci. 2006, 20, 193-213. [CrossRef]

55. Lindsay, J.B.; Cockburn, J.M.H.; Russell, H.A.J. An integral image approach to performing multi-scale topographic position analysis. Geomorphology 2015, 245, 51-61. [CrossRef]

56. Antoni, O.; Hatic, D.; Pernar, R. DEM-based depth in sink as an environmental estimator. Ecol. Modell. 2001, 138, 247-254. [CrossRef]

57. Hjerdt, K.N.; McDonnell, J.J.; Seibert, J.; Rodhe, A. A new topographic index to quantify downslope controls on local drainage. Water Resour. Res. 2004, 40,1-6. [CrossRef]

58. Moore, I.D.; Burch, G.J. Modelling erosion and deposition: Topographic effects. Trans. Am. Soc. Agric. Eng. 1986, 29, 1624-1630. [CrossRef]

59. Gómez-Gutiérrez, Á.; Conoscenti, C.; Angileri, S.E.; Rotigliano, E.; Schnabel, S. Using topographical attributes to evaluate gully erosion proneness (susceptibility) in two mediterranean basins: Advantages and limitations. Nat. Hazards 2015, 79, 291-314. [CrossRef]

60. Beven, K.J.; Kirkby, M.J. A physically based, variable contributing area model of basin hydrology. Hydrol. Sci. Bull. 1979, 24, 43-69. [CrossRef]

61. Zevenbergen, L.W.; Thorne, C.R. Quantitative analysis of land surface topography. Earth Surf. Process. Landforms 1987, 12, 47-56. [CrossRef] 
62. Koethe, R.; Lehmeier, F. SARA—System zur Automatischen Relief-Analyse. User Manual, 2nd ed.; 1996; unpublished.

63. Olaya, V.; Conrad, O. Geomorphometry in SAGA. In Developments in Soil Science; Hengl, T., Reuter, H.I., Eds.; Elsevier B.V.: Oxford, UK, 2009; Volume 33, pp. 293-308.

64. Leempoel, K.; Parisod, C.; Geiser, C.; Daprà, L.; Vittoz, P.; Joost, S. Very high-resolution digital elevation models: Are multi-scale derived variables ecologically relevant? Methods Ecol. Evol. 2015, 6, 1373-1383. [CrossRef]

65. Blaga, L. Aspects regarding the significance of the curvature types and values in the studies of geomorphometry assisted by GIS. Analele Univ. din Oradea -Ser. Geogr. 2012, 22, 327-337.

66. Wood, J.D. The Geomorphological Characterisation of Digital Elevation Models. Ph.D. Thesis, University of Leicester, Leicester, UK, 1996.

67. Shary, P.A.; Sharaya, L.S.; Mitusov, A.V. Fundamental quantitative methods of land surface analysis. Geoderma 2002, 107, 1-32. [CrossRef]

68. Freeman, T.G. Calculating catchment area with divergent flow based on a regular grid. Comput. Geosci. 1991, 17, 413-422. [CrossRef]

69. Gallant, J.C.; Dowling, T.I. A multiresolution index of valley bottom flatness for mapping depositional areas. Water Resour. Res. 2003, 39, 1-14. [CrossRef]

70. Weiss, A. Topographic position and landforms analysis. In Proceedings of the Poster Presentation, ESRI User Conference, San Diego, CA, USA, 9-13 July 2001; Volume 64, pp. 227-245.

71. Guisan, A.; Weiss, S.B.; Weiss, A.D.; Ecology, S.P.; Weiss, D. GLM versus CCA spatial modeling of plant species distribution. Plant. Ecol. 2011, 143, 107-122. [CrossRef]

72. Yokoyama, R.; Shirasawa, M.; Pike, R.J. Visualizing topography by openness: A new application of image processing to digital elevation models. Photogramm. Eng. Remote. Sens. 2002, 68, 257-265.

73. MacMillan, R.A.; Shary, P.A. Landforms and landform elements in geomorphometry. In Developments in Soil Science; Hengl, T., Reuter, H.I., Eds.; Elsevier B.V.: Oxford, UK, 2009; Volume 33, pp. 227-254. ISBN 0166-2481.

74. Cristea, N.C.; Breckheimer, I.; Raleigh, M.S.; HilleRisLambers, J.; Lundquist, J.D. An evaluation of terrain-based downscaling of fractional snow covered area data sets based on LiDAR-derived snow data and orthoimagery. Water Resour. Res. 2017, 53, 6802-6820. [CrossRef]

75. Sappington, J.M.; Longshore, K.M.; Thomson, D.B. Quantifying landscape ruggedness for animal habitat analysis: A case study using bighorn sheep in the Mojave Desert. J. Wildl. Manag. 2007, 71, 1419-1426. [CrossRef]

76. Chen, Q.; Meng, Z.; Liu, X.; Jin, Q.; Su, R. Decision variants for the automatic determination of optimal feature subset in RF-RFE. Genes 2018, 9, 301. [CrossRef]

77. Kuhn, M.; Wing, J.; Weston, S.; Williams, A.; Keefer, C.; Engelhardt, A.; Cooper, T.; Mayer, Z.; Ziem, A.; Scrucca, L.; et al. Package 'caret' R: Classification and Regression Training; Version 6.0-86. CRAN Repository; 2020.

78. Belgiu, M.; Drăgut, L. Random forest in remote sensing: A review of applications and future directions. ISPRS J. Photogramm. Remote. Sens. 2016, 114, 24-31. [CrossRef]

79. Breiman, L. Random Forest. Mach. Learn. 2001, 45, 5-32. [CrossRef]

80. Gislason, P.O.; Benediktsson, J.A.; Sveinsson, J.R. Random forests for land cover classification. Pattern Recognit. Lett. 2006, 27, 294-300. [CrossRef]

81. Jin, Y.; Liu, X.; Chen, Y.; Liang, X. Land-cover mapping using Random Forest classification and incorporating NDVI time-series and texture: A case study of central Shandong. Int. J. Remote. Sens. 2018, 39, 8703-8723. [CrossRef]

82. Eisavi, V.; Homayouni, S.; Yazdi, A.M.; Alimohammadi, A. Land cover mapping based on random forest classification of multitemporal spectral and thermal images. Environ. Monit. Assess. 2015, 187, 1-14. [CrossRef]

83. Schlosser, A.D.; Szabó, G.; Bertalan, L.; Varga, Z.; Enyedi, P.; Szabó, S. Building extraction using orthophotos and dense point cloud derived from visual band aerial imagery based on machine learning and segmentation. Remote. Sens. 2020, 12, 2397. [CrossRef]

84. Phinzi, K.; Abriha, D.; Bertalan, L.; Holb, I.; Szabó, S. Machine learning for gully feature extraction based on a pan-sharpened multispectral image: Multiclass vs. Binary approach. ISPRS Int. J. Geo-Inf. 2020, 9, 252. [CrossRef] 
85. Zhu, J.; Pierskalla, W.P. Applying a weighted random forests method to extract karst sinkholes from LiDAR data. J. Hydrol. 2016, 533, 343-352. [CrossRef]

86. Lawrence, R.L.; Wood, S.D.; Sheley, R.L. Mapping invasive plants using hyperspectral imagery and Breiman Cutler classifications (RandomForest). Remote. Sens. Environ. 2006, 100, 356-362. [CrossRef]

87. Therneau, T.; Atkinson, B.; Ripley, B. Package rpart: Recursive Partitioning and Regression Trees; Version 4.1-15. CRAN Repository; 2019.

88. Van der Linden, S.; Rabe, A.; Held, M.; Jakimow, B.; Leitão, P.J.; Okujeni, A.; Schwieder, M.; Suess, S.; Hostert, P. The EnMAP-box-A toolbox and application programming interface for EnMAP data processing. Remote. Sens. 2015, 7, 11249-11266. [CrossRef]

89. Congalton, R.G. A review of assessing the accuracy of classifications of remotely sensed data. Remote. Sens. Environ. 1991, 37, 35-46. [CrossRef]

90. Powers, D.M.W. Evaluation: From Precision, Recall and F-Factor to ROC, Informedness, Markedness E Correlation; Technical Report; School of Informatics and Engineering Flinders University of South Australia: Adelaide, Australia, 2007.

91. Chicco, D.; Jurman, G. The advantages of the Matthews correlation coefficient (MCC) over F1 score and accuracy in binary classification evaluation. BMC Genom. 2020, 21,1-13. [CrossRef]

92. Boström, H. Estimating class probabilities in random forest. In Proceedings of the Proceedings-6th International Conference on Machine Learning and Applications (ICMLA 2007), Cincinnati, OH, USA, 13-15 December 2007; pp. 211-216.

93. Lima, E.D.P.; Barreto, S.M.; Assunção, A.Á. Factor structure, internal consistency and reliability of the Posttraumatic Stress Disorder Checklist (PCL): An exploratory study. Trends Psychiatry Psychother. 2012, 34, 215-222. [CrossRef]

94. Albers, C.; Lakens, D. When power analyses based on pilot data are biased: Inaccurate effect size estimators and follow-up bias. J. Exp. Soc. Psychol. 2018, 74, 187-195. [CrossRef]

95. Field, A. Discovering Statistics Using IBM SPSS Statistics, 4th ed.; SAGE Publications Ltd.: London, UK, 2013; ISBN 978-9351500827.

96. Gallucci, M. Package Gamlj: GAMLj Suite for Jamovi; Version 2.0.5. GitHub Repository; 2020.

97. Wei, T.; Simko, V.; Levy, M.; Xie, Y.; Jin, Y.; Zemla, J. R package "corrplot": Visualization of a Correlation Matrix. Statistician 2017, 56, 316-324.

98. Gudiyangada Nachappa, T.; Kienberger, S.; Meena, S.R.; Hölbling, D.; Blaschke, T. Comparison and validation of per-pixel and object-based approaches for landslide susceptibility mapping. Geomatics, Nat. Hazards Risk 2020, 11, 572-600. [CrossRef]

99. Kamal, M.; Phinn, S. Hyperspectral data for mangrove species mapping: A comparison of pixel-based and object-based approach. Remote. Sens. 2011, 3, 2222-2242. [CrossRef]

100. Belgiu, M.; Csillik, O. Sentinel-2 cropland mapping using pixel-based and object-based time-weighted dynamic time warping analysis. Remote. Sens. Environ. 2018, 204, 509-523. [CrossRef]

101. Whiteside, T.G.; Boggs, G.S.; Maier, S.W. Comparing object-based and pixel-based classifications for mapping savannas. Int. J. Appl. Earth Obs. Geoinf. 2011, 13, 884-893. [CrossRef]

102. Rotigliano, E.; Martinello, C.; Agnesi, V.; Conoscenti, C. Evaluation of debris flow susceptibility in El Salvador (CA): A comparisobetween multivariate adaptive regression splines (MARS) and binary logistic regression (BLR). Hungarian Geogr. Bull. 2018, 67, 361-373. [CrossRef]

103. Varga, O.G.; Szabó, S.; Túri, Z. Efficiency assessments of GEOBIA in land cover analysis, NE Hungary. Bull. Environ. Sci. Res. 2014, 3, 1-9.

104. Szabó, L.; Burai, P.; Deák, B.; Dyke, G.J.; Szabó, S. Assessing the efficiency of multispectral satellite and airborne hyperspectral images for land cover mapping in an aquatic environment with emphasis on the water caltrop (Trapa natans). Int. J. Remote. Sens. 2019, 40, 5192-5215. [CrossRef]

105. Lin, C.W.; Wen, T.C.; Setiawan, F. Evaluation of vertical ground reaction forces pattern visualization in neurodegenerative diseases identification using deep learning and recurrence plot image feature extraction. Sensors 2020, 20, 3857. [CrossRef]

106. Machidon, A.L.; Del Frate, F.; Picchiani, M.; Machidon, O.M.; Ogrutan, P.L. Geometrical approximated principal component analysis for hyperspectral image analysis. Remote. Sens. 2020, 12, 1698. [CrossRef]

107. Scarrott, R.G.; Cawkwell, F.; Jessopp, M.; O’Rourke, E.; Cusack, C.; De Bie, K. From land to sea, a review of hypertemporal remote sensing advances to support ocean surface science. Water 2019, 11, 2286. [CrossRef] 
108. Prieto-Amparán, J.A.; Pinedo-Alvarez, A.; Vázquez-Quintero, G.; Valles-Aragón, M.C.; Rascón-Ramos, A.E.; Martinez-Salvador, M.; Villarreal-Guerrero, F. A multivariate geomorphometric approach to prioritize erosion-prone watersheds. Sustainability 2019, 11, 5140. [CrossRef]

109. Lecours, V.; Simms, A.; Devillers, R.; Lucieer, V.; Edinger, E. Finding the Best Combinations of Terrain Attributes and GIS software for Meaningful Terrain Analysis. In Geomorphometry for Geosciences; Jasiewicz, J., Zwolinski, Z., Mitasova, H., Hengl, T., Eds.; Bogucki Wydawnictwo Naukowe, Adam Mickiewicz University in Poznan - Institute of Geoecology and Geoinformation: Poznan, Poland, 2015; pp. 133-136.

110. Ahmadi, K.; Kalantar, B.; Saeidi, V.; Harandi, E.K.G.; Janizadeh, S.; Ueda, N. Comparison of Machine Learning Methods for Mapping the Stand Characteristics of Temperate Forests Using Multi-Spectral Sentinel-2 Data. Remote Sens. 2020, 12, 3019. [CrossRef]

111. Szabó, Z.; Buró, B.; Szabó, J.; Tóth, C.A.; Baranyai, E.; Herman, P.; Prokisch, J.; Tomor, T.; Szabó, S. Geomorphology as a driver of heavy metal accumulation patterns in a floodplain. Water 2020, $12,563$. [CrossRef]

Publisher's Note: MDPI stays neutral with regard to jurisdictional claims in published maps and institutional affiliations.

(C) 2020 by the authors. Licensee MDPI, Basel, Switzerland. This article is an open access article distributed under the terms and conditions of the Creative Commons Attribution (CC BY) license (http://creativecommons.org/licenses/by/4.0/). 